Linköping Studies in Science and Technology

Thesis No. 1770

\title{
FAILURE MECHANISMS IN APS AND SPS THERMAL BARRIER COATINGS DURING CYCLIC OXIDATION AND HOT CORROSION
}

Krishna Praveen Jonnalagadda

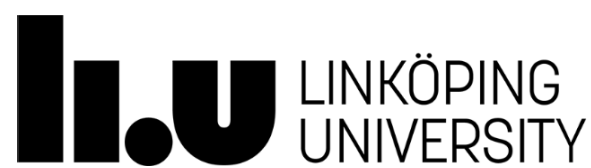

Division of Engineering Materials

Department of Management and Engineering (IEI)

Linköping University, SE - 58183 Linköping, Sweden

Linköping 2017 
Front page image: The top view of yttria stabilized zirconia thermal barrier coating after exposure to a salt mixture of vanadium pentoxide and sodium sulfate at $900{ }^{\circ} \mathrm{C}$.

During the course of research underlying this thesis, Krishna Praveen Jonnalagadda was enrolled in Agora Materiae, a multidisciplinary doctoral program at Linköping University, Sweden.

ISBN: 978-91-7685-594-2

ISSN: 0280-7971

Printed by LiU-Tryck 2017 


\begin{abstract}
Thermal Barrier Coatings (TBCs) are advanced material systems that are being used in the hot sections of gas turbines such as combustor, turbine blades, and vanes. The top ceramic coating in TBCs provides insulation against the hot gases and the intermediate metallic bond coat provides oxidation and corrosion resistance to the underlying turbine components.

Durability of thermal barrier coatings is very important for the overall performance of the gas turbine. TBCs can fail in several different ways and there is a combination of more than one failure mechanism in most situations. One of the most widely used TBC is atmospheric plasma sprayed (APS) yttria stabilized zirconia (YSZ). Both the deposition technique and the TBC material have certain limitations. The main aim of this research is to study new TBC materials and/or new deposition techniques and compare with the conventional YSZ and understand their failure mechanisms during cyclic oxidation and hot corrosion.
\end{abstract}

Thermal cyclic oxidation of a newly developed high purity nano YSZ thermal barrier coating has been studied. Cross sectional analysis of exposed as well as completely failed samples showed a mixed-type failure caused by crack propagation parallel to the bond coat/top coat interface. The majority of the damage occurred towards the end of the coating life. A finite element model has been developed to study the probability of crack growth along different paths that leads to the final failure.

Hot corrosion mechanism in suspension plasma sprayed two-layer gadolinium zirconate/YSZ, three-layer dense gadolinium zirconate/gadolinium zirconate/YSZ, and a single-layer YSZ has been studied in the presence of sodium sulfate and vanadium pentoxide. The test results showed that gadolinium zirconate coatings were more susceptible to corrosion compared to YSZ coatings despite gadolinium zirconate coatings having lower reactivity with the corrosive salts.

Thermal cycling behavior of a high chromium bond coat has been studied. Cross-sectional analysis showed formation of sandwich type microstructure with chromium rich oxide and alumina as the top and the bottom layers.

Inter-diffusion of minor elements between different MCrAlY coatings - substrate systems has been studied using, diffusion simulation software, DICTRA. The simulation results showed that the diffusion of minor elements in the coatings is dependent on the rate of $\beta$ phase depletion in the beginning. After the depletion of $\beta$ phase there was no clear dependence of the coating composition on the diffusion of minor elements. 



\section{Sammanfattning}

Termiska barriärskikt, eller TBC från engelskans thermal barrier coating, är avancerade materielsystem som används i de varmaste delarna av en gasturbin såsom brännkammare, turbinskovlar och ledskenor. Det övre keramiska skiktet isolerar mot den höga temperaturen i förbränningsgasen och det mellanliggande metalliska skiktet ger oxidations- och korrosionsmotstånd åt den underliggande turbinkomponenten.

God hållfasthet och beständighet hos termiska barriärskikt är viktigt för gasturbiners prestanda. TBC:n kan haverera genom ett flertal mekanismer och ofta förekommer mer än en samtidigt. Den vanligast använda TBC:n tillverkas genom plasmasprutning i luft, APS från engelskans atmospheric plasma spraying, och består av yttriumoxidstabiliserad zirkoniumoxid (YSZ). Både tillverkningstekniken och TBC-materialet har vissa begränsningar. Främsta syftet med denna forskning är att studera nya TBC-material och/eller nya tillverkningstekniker jämfört med konventionell TBC och att förstå skademekanismer under cyklisk oxidation och varmkorrosion.

Oxidation under termisk cykling har studerats hos ett nyligen utvecklat termiskt barriärskikt bestående av nano-YSZ med hög renhet. Analys av tvärsnitt hos exponerade och havererade prov uppvisade brott av blandad typ orsakad av sprickväxt parallellt med gränssnittet mellan bindskikt och toppskikt. Merparten av skadan uppstod mot slutet av skiktets livslängd. En finita-elementmodell har skapats för att studera rimligheten hos spricktillväxt längs olika spricktillväxtvägar som leder till slutgiltigt brott.

Varmkorrosionsmekanismer har studerats hos tre varianter av suspensionsplasmasprutade skiktsystem: gadoliniumzirkonat/YSZ, tät gadoliniumzirkonat/gadoliniumzirkonat/YSZ och YSZ. Korrosionsprovningen utfördes med natriumsulfat och vanadinpentoxid. Resultaten visade att gadoliniumzirkonatskikt var mer känsliga för korrosion jämfört med YSZ-skikt trots att gadoliniumzirkonatskikten hade lägre reaktivitet med de korrosiva salterna.

Beteendet under termisk cykling har studerats för bindskikt med hög kromhalt. Analys av tvärsnitt visade en skiktad mikrostruktur hos oxiden med kromoxid och aluminiumoxid som övre respektive undre skikt.

Interdiffusion av legeringsämnen mellan olika MCrAlY-substratsystem har studerats med mjukvaran DICTRA. Resultat från dessa simuleringar visade att diffusionen av legeringsämnen inledningsvis beror på hastigheten hos $\beta$-fasutarmningen. Diffusionen av legeringsämnen efter det att $\beta$-fasutarmning hade skett visade inget klart samband med skiktets sammansättning. 



\section{摘要}

热障涂层 (TBCs) 是目前最先进的高温防护涂层之一, 被广泛应用于燃气浴轮机的燃烧 室和浴轮叶片等高温构件中。实际应用的热障涂层大多采用双层结构：陶瓷表层提供隔 热性能，金属粘结底层（MCrAlY）为工作基体金属部件提供抗高温氧化和腐蚀保护作 用。

热障涂层的使用寿命对于气浴轮机的整体性能至关重要。涂层的结构特点和应用环境导 致热障涂层出现多种失效形式，而不同的失效形式一般受多个失效机理控制。大气离子 喷涂（APS）是传统的热障涂层制备方法之一，而氧化钇稳定的氧化锆（YSZ）是目前使 用最广泛的陶瓷隔热表层材料, 但是大气等离子喷涂和氧化钎稳定的氧化锆材料都有其 局限性。本文主要通过使用新型 $\mathrm{TBC}$ 材料并运用新喷涂方法来研究热障涂层在循环氧 化和热腐蚀实验中的失效机理。

本文研究了一种新型抗烧结高纯纳米热障材料。通过分析失效样品横截面, 发现失效是 由陶瓷层中出现平行于表面的横向裂纹扩展导致的混合失效模式控制, 横向裂纹在服役 过程中扩散最终造成 TBC 的横向开裂。

本文研究了三种通过悬浮液等离子喷涂方法制备的热障涂层材料在硫酸钠和氧化钒环境 下热腐蚀机理, 三种热障涂层材料分别是: 单层 YSZ, 双层 $\mathrm{Gd}_{2} \mathrm{Zr}_{2} \mathrm{O}_{7} / \mathrm{YSZ}$ 和三 层致密 $\mathrm{Gd}_{2} \mathrm{Zr}_{2} \mathrm{O}_{7} / \mathrm{Gd}_{2} \mathrm{Zr}_{2} \mathrm{O}_{7} / \mathrm{YSZ}$ 。实验结果显示尽管 $\mathrm{Gd}_{2} \mathrm{Zr}_{2} \mathrm{O}_{7}$ 在熔盐中更稳定, 但是 它的抗腐蚀性能较 YSZ 相比更弱。

本文同时研究了高铬含量金属粘结层的循环氧化行为。通过观察热生长氧化层（TGO） 横截面，发现由表层氧化铬和里层氧化铝组成的双层结构。

本文通过使用 DICTRA 模拟软件, 研究了微量元素在不同 MCrAlY 涂层和基体的互扩 散行为。模拟结果显示: 微量元素在涂层中的扩散是受 MCrAlY 涂层中 $\beta$ 相损耗控 制; 当 $\beta$ 相完全消失后，无证据显示微量元素扩散受 MCrAlY 涂层成分影响。 



\section{Acknowledgements}

The present work has been performed at the Division of Engineering Materials, Linköping University, Sweden and has been funded by Vinnova in Sweden which is gratefully acknowledged. The work is carried out in close collaboration with Siemens Industrial Turbomachinery, Finspång, Sweden and Beijing General Research Institute of Mining and Metallurgy (BGRIMM), Beijing, People's Republic of China.

During the course of my research, I have received support from several people for whom I am truly thankful. In a sincere attempt not to miss anyone, my gratitude goes to:

Firstly, my main supervisor, Associate Professor. Ru Lin Peng, for giving me the opportunity and providing continuous guidance and support to my research. It has been a real pleasure working with and learning from you. The valuable discussions during the day long monthly project meetings have really provided direction to this project.

Secondly, my co-supervisor Dr. Xin-Hai Li, Siemens Industrial Turbomachinery AB, for providing valuable suggestions and providing great support throughout the research. To my other co-supervisors Dr. Robert Eriksson for sharing his knowledge on thermal barrier coatings during this research and translating the abstract to Swedish. To Professor. Sten Johansson for providing valuable inputs to this work.

I would like to thank Dr. Kang Yuan for helping me with the practical things at the beginning of this work. Thanks for your interesting ideas, collaboration and for providing a lot of samples!

Thanks to Mrs. Annethe Billenius for making sure the lab supplies never ever run out and for providing support to the practical work in the lab.

I would like to thank all my colleagues for creating a good research environment in the division. Thanks to Pimin for good discussions related to coatings which has improved my knowledge and for translating the abstract to Chinese.

A special thanks to Mrs. Ingmari Hallkvist for providing the best administrative support.

To Högskolan Väst, Sweden, for providing the SPS samples.

To my parents, because of whom I am where I am today. Finally, to my wife and best friend, Sharu, for leaving everything back at home and moving to Sweden. I couldn't have asked for a better person to walk into my life!. 



\section{List of appended papers}

\section{Paper I}

Krishna Praveen Jonnalagadda, Robert Eriksson, Kang Yuan, Xin-Hai Li, Yueguang Yu and Ru Lin Peng, "A study of damage evolution in high purity nano TBCs during thermal cycling: A fracture mechanics based modelling approach", Submitted to Journal of the European Ceramic Society.

\section{Paper II}

Krishna Praveen Jonnalagadda, Satyapal Mahade, Nicholas Curry, Xin-Hai Li, Nicolaie Markocsan, Per Nylén, Stefan Björklund and Ru Lin Peng, "Hot Corrosion mechanism in multilayer suspension plasma sprayed $\mathrm{Gd}_{2} \mathrm{Zr}_{2} \mathrm{O}_{7} / \mathrm{YSZ}$ thermal barrier coatings in the presence of $\mathrm{V}_{2} \mathrm{O}_{5}+\mathrm{Na}_{2} \mathrm{SO}_{4}$ ", Journal of Thermal Spray Technology, vol. 26, pp. 140-149, 2017.

\section{Paper III}

Kang Yuan, Krishna Praveen Jonnalagadda, Yueguang Yu, Ru Lin Peng, Xin-Hai Li, Xiaojuan $\mathrm{Ji}$ and Jie Shen, "Thermal fatigue failure of thermal barrier coatings with a high Cr-MCrAlY bond coat", Proceedings of the International Thermal Spray Conference (ITSC), May 10-12, China, pp. 273-278, 2016.

\section{Paper IV}

Krishna Praveen Jonnalagadda, Kang Yuan, Xin-Hai Li, Yueguang Yu and Ru Lin Peng, "Modelling the diffusion of minor elements in different MCrAlY-Superalloy coating/ substrates at high temperature", Accepted - To appear in the proceedings of TMS, Feb 26Mar 2, USA, 2017.

Author's contribution: As the main author in the papers I, II and IV, I performed all the experiments, dictra simulations and analysis on the samples. I was the main contributor for the manuscript. Modelling related work in Paper I was done by my co-author Robert Eriksson. The diffusion depth and diffusivity calculations (Fig. 9 and Table 2.) in paper IV was done by my co-author Kang Yuan.

As a second author in Paper III, I performed all the experimental work and analysis and contributed to writing the manuscript. 


\section{List of papers not included in the thesis}

\section{Paper V}

Krishna Praveen Jonnalagadda, Robert Eriksson, Ru Lin Peng, Xin-Hai Li, and Sten Johansson, "Factors affecting the performance of thermal barrier coatings in the presence of $\mathrm{V}_{2} \mathrm{O}_{5}$ and $\mathrm{Na}_{2} \mathrm{SO}_{4}$ ", Journal of Ceramic Science and Technology, vol. 7, pp. 409-416, 2016.

\section{Paper VI}

Robert Eriksson and Krishna Praveen Jonnalagadda, "A study on crack configurations in thermal barrier coatings", Submitted to ASME Turbo Expo, June 26-30, North Carolina, USA, 2017. 


\title{
Acronyms
}

\author{
APS - Atmospheric Plasma Spraying \\ BC - Bond Coat \\ CTE - Coefficient of Thermal Expansion \\ DGZ - Dense Gadolinium Zirconate \\ EB-PVD - Electron Beam Physical Vapor Deposition \\ EDS - Energy Dispersive X-ray Spectroscopy \\ FEM - Finite Element Model \\ GZ - Gadolinium Zirconate \\ HVAF - High Velocity Air Fuel \\ HVOF - High Velocity Oxy Fuel \\ SEM - Scanning Electron Microscopy \\ SPS - Suspension Plasma Spraying \\ TBC - Thermal Barrier Coatings \\ TC - Top Coat \\ TCF - Thermal Cyclic Fatigue \\ TGO - Thermally Grown Oxide \\ WDS - Wave length Dispersive X-ray Spectroscopy \\ XRD - X-ray Diffraction \\ YSZ - Yttria Stabilized Zirconia
}





\section{Thesis Outline}

The current thesis is divided into two parts; Part A and Part B.

\section{Part A}

Part A gives the required introduction to understand and follow the results in Part B. Part A is divided into eight chapters.

\section{Part B}

Part B discusses the outcome of the research questions included in Part A. The outcomes are discussed in the form of scientific publications. 

Part - A

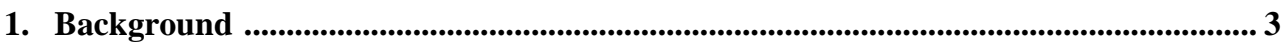

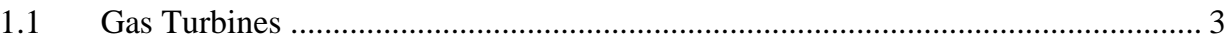

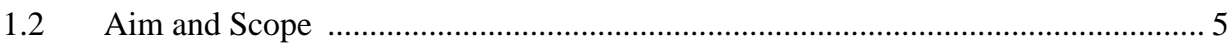

2. Thermal Barrier Coatings (TBCs) - Materials and Deposition Techniques................. 7

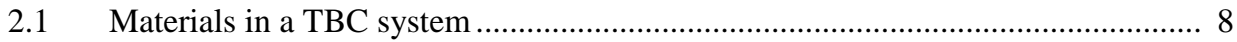

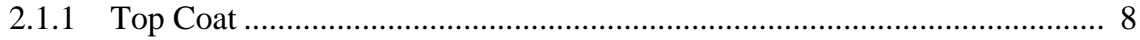

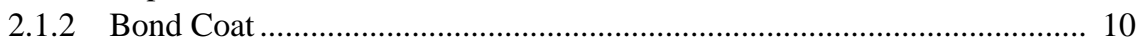

2.1.3 Thermally Grown Oxide ............................................................................... 11

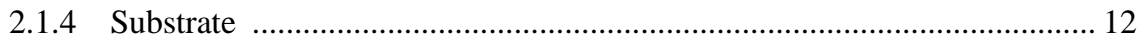

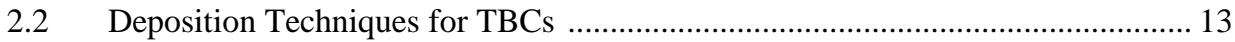

2.2.1 Atmospheric Plasma Spraying ………………………………………. 13

2.2.2 Suspension Plasma Spraying ....................................................................... 14

3. TBC failure mechanisms ……........................................................................................ 17

3.1 Thermal Cyclic Tests-Failure mechanisms ………………………………..... 17

3.2 Hot corrosion tests-Failure mechanisms …………………………………..... 20

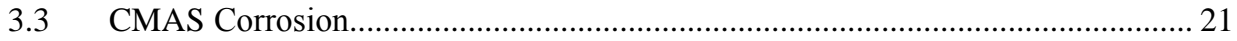

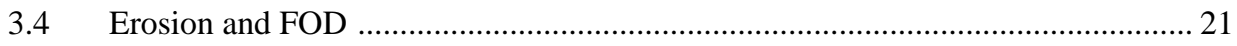

3.5 Other factors related to TBCs processing .......................................................... 21

4. Modelling ………..................................................................................................................... 23

$4.1 \quad$ Inter-diffusion modelling ................................................................................. 23

$4.2 \quad$ Crack growth modelling ................................................................................ 24

5. Experimental Characterization ............................................................................................ 27

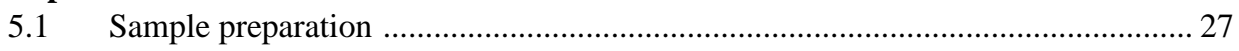

5.2 Porosity measurement …………………………………………………….... 27

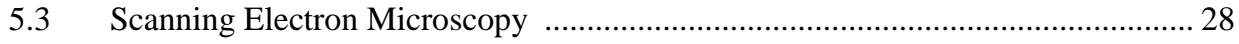

5.3.1 Secondary electron detector …………………………………………..... 29

5.3.2 Backscatter electron detector .................................................................... 29

5.3.3 Energy Dispersive X-ray Spectroscopy ………………………………..... 29

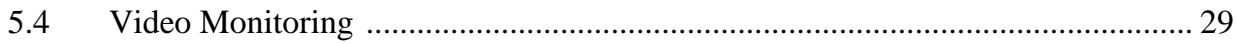

6. Summary ……...................................................................................................................... 31

7. Conclusions …..................................................................................................................... 35

8. Future Work ………....................................................................................................................... 37

Bibliography ……….................................................................................................................. 39 


\section{Part - B}

Paper 1: A study of damage evolution in high purity nano TBCs during thermal cycling: A fracture mechanics based modelling approach

Paper II: Hot Corrosion mechanism in multi-layer suspension plasma sprayed $\mathrm{Gd}_{2} \mathrm{Zr}_{2} \mathrm{O}_{7}$ /YSZ thermal barrier coatings in the presence of $\mathrm{V}_{2} \mathrm{O}_{5}+\mathrm{Na}_{2} \mathrm{SO}_{4}$

Paper III: Thermal fatigue failure of thermal barrier coatings with a high Cr-MCrAIY bond coat

Paper IV: Modelling the diffusion of minor elements in different MCrAIY-Superalloy coating/substrates at high temperature 
PART - A 



\section{Background}

This work was started as a co-operation between Siemens Industrial Turbomachinery AB, Finspång, Sweden, Linköping University, Linköping, Sweden, and Beijing General Research Institute of Mining and Metallurgy (BGRIMM), Beijing, People's Republic of China. The broader objective of this work is to provide the industry with new coating systems, new deposition processes along with optimizing the existing deposition processes and provide lifing tools for different coating systems. All of this may enable to run a land-based gas turbine or aero-engines at higher temperatures which will result in higher thermal efficiency.

\subsection{Gas turbines}

Gas turbines are used for two purposes: as land-based gas turbines for generating electricity and driving machineries such as compressors for pumping natural gas, propellers for ships etc. and as engines for powering aircrafts, and tanks. Based on the type of application, the design might vary but the overall operation principle remains the same. Gas turbines are manufactured in different sizes ranging from low-power generation to high power generation. For instance, the gas turbines developed and produced by Siemens range from a mere $4 \mathrm{MW}$ to up to $425 \mathrm{MW}$. A basic gas turbine is illustrated in Fig. 1 below.

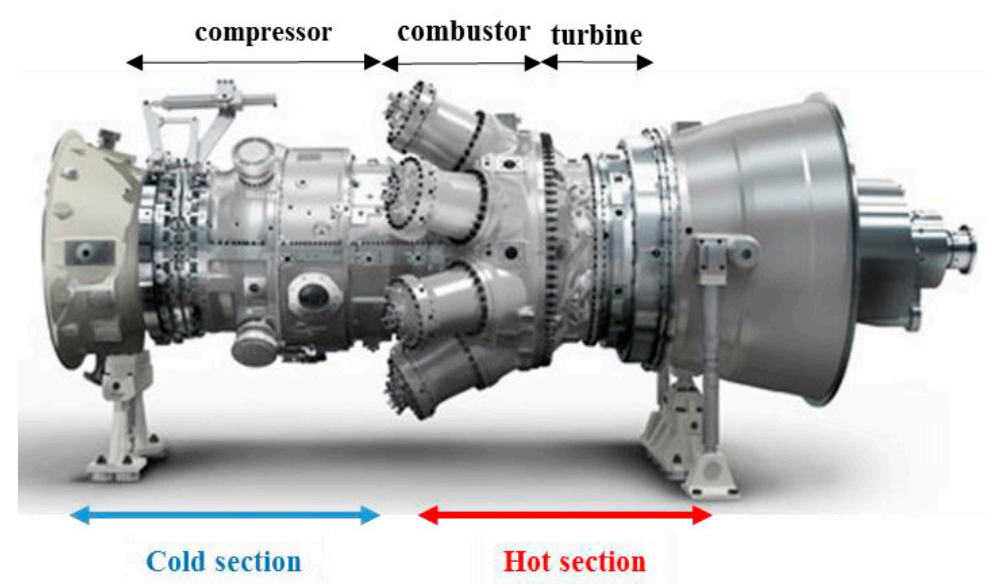

Fig. 1 A land based gas turbine showing the hot and the cold sections. Courtesy of Siemens

As can be seen from Fig. 1, the gas turbine has three main sections; 
a. Compressor: Air from the atmosphere is sucked into the compressor where it gets compressed. The temperature in the compressor part of the gas turbine is low relative to the other two parts and hence it is considered a cold section.

b. Combustor: The combustor accepts air from the exit of the compressor and delivers it to the turbine at a higher temperature. Here the fuel is injected into the compressed air through the burners. The inlet temperature of air in the combustion chamber ranges from $541{ }^{\circ} \mathrm{C}-614$ ${ }^{\circ} \mathrm{C}$ for a low pressure rate regenerative gas turbine and $686{ }^{\circ} \mathrm{C}-857^{\circ} \mathrm{C}$ for a high pressure ratio gas turbine. Combustor exit temperatures range from $927{ }^{\circ} \mathrm{C}-1593{ }^{\circ} \mathrm{C}$ [1].

c. Turbine: The turbine inlet temperature is the same as the combustor exit temperature. Here the gases (at high temperature and pressure) expand along the turbine blades and rotate them changing the form of energy from heat to mechanical. The gases flow through different turbine stages and the first stage of turbine which is the closest to the combustor experiences the highest temperature. The mechanical energy from the turbine is later converted into electrical energy by connecting to an electric generator. Alternatively, the energy can be used to drive a fan and the high pressure of the gases at the exhaust provide thrust to propel an aircraft forward.

The thermal efficiency $(\eta)$ of a gas turbine following an ideal Carnot cycle [2] is given by Eq. (1).

$$
\eta=1-\left(\mathrm{T}_{\text {exit }} / \mathrm{T}_{\text {inlet }}\right)
$$

where $\mathrm{T}_{\text {exit }}$ and $\mathrm{T}_{\text {inlet }}$ represent the exit and the inlet temperatures of the turbine. From this equation, it is clear that increasing the turbine inlet temperature can increase the thermal efficiency of the gas turbine.

Currently, the best class of materials for turbine blade applications are manufactured with single-crystal Ni-based superalloys that exhibit exceptional creep resistance at high temperatures [3]. The upper operating limit for these materials will be their melting point. Turbine inlet temperatures of about $1600{ }^{\circ} \mathrm{C}$ are possible only when the components are shielded from the harsh conditions in the turbine with some form of protection. The insulation of turbine components from the hot gases are offered through thermal barrier coatings. Along with the use of coating, part of the air from the compressor exit is bypassed the combustor to cool the turbine blades. However, the cooling schemes are limited to the amount of air they can use without resulting in a drop in the thermal efficiency. As a rule of thumb, if more than $8 \%$ of the air is being used for cooling then the advantage of higher operating temperature is lost [1]. By improving the design and deposition of these thermal barrier coatings a further increase in thermal efficiency of gas turbines is possible. Alongside, it becomes very important to understand the performance of these coatings as their failure will directly expose the underlying turbine components to very high temperatures. 


\subsection{Aim and scope of the present work}

Design of new coatings, optimizing the existing deposition processes and working with new deposition techniques, understanding the failure mechanisms in new materials/process by testing followed by extensive characterization and comparing them with the conventional materials together form the basis of this work.

In line with the above aims, the scope of the present work, that also formed the basis for the research questions are given below.

a. To understand the damage development and failure mechanism in a newly developed high purity nano thermal barrier coating during thermal cyclic tests and use modelling as a tool to explain the observed phenomena

b. To study the corrosion mechanism in a multi-layer suspension plasma sprayed (SPS) coating and compare it with a reference single-layer SPS YSZ coating

c. To understand the damage development in a newly developed high Cr-low Al bond coatYSZ thermal barrier coating during thermal cyclic tests

d. To study the diffusion of minor elements in different MCrAlY - Substrate systems 



\section{2}

\section{Thermal Barrier Coatings - Materials and Deposition Techniques}

Thermal barrier coatings (TBCs) are advanced material systems that are being used in the hot sections of gas turbines [4] and diesel engines. TBCs typically have a two layer structure where the top coat is made of ceramic and offers thermal insulation from the hot gases. Below the top coat is a metallic bond coat that offers resistance against oxidation and corrosion at high temperatures. The bond coat is applied on the surface of the turbine component, typically made of a Ni-based superalloy. Together, they constitute the thermal barrier coating system. There is a fourth constituent of TBC system, a thermally grown oxide (TGO). TGO is a reaction product that forms at the bond coat/top coat interface when the coating is exposed to high temperature. TBCs are considered advanced systems because the microstructure changes with exposure time. When exposed to high temperature, TGO growth occurs and diffusion of elements to/from the bond coat and the substrate takes place resulting in a change of properties of the substrate and the bond coat. All these changes happen simultaneously and together with the changes in the top coat microstructure, make the TBC system complex to analyze as each change may affect the performance of the TBCs.

A typical microstructure of TBC system, deposited using atmospheric plasma spraying, along with the temperature distribution is shown in Fig. 2.

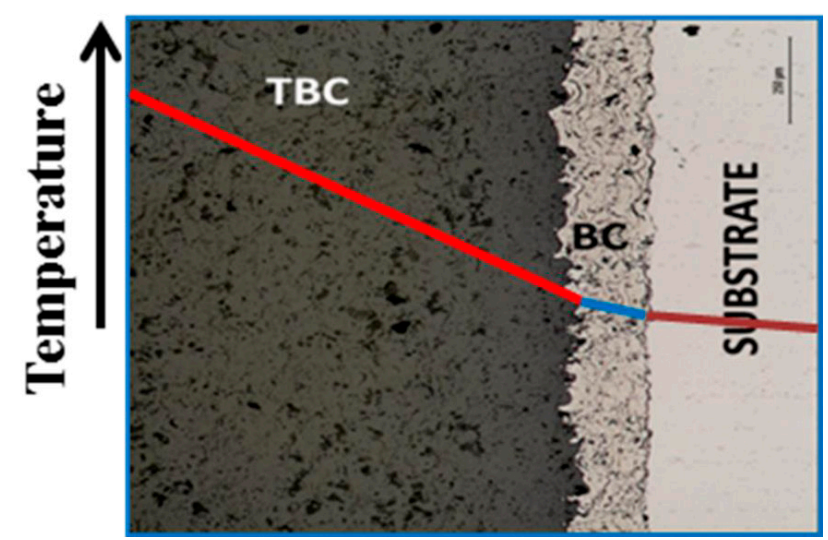

Fig. 2 Temperature gradient in a TBC system across different layers

As can be seen from Fig. 2, there is a significant temperature gradient through the top coat, while the temperature gradient in the bond coat and the substrate is much lower. Each layer of the thermal barrier coating system is discussed in detail in the sections below. Although, the applications of TBCs vary, the discussion in the present research is mostly limited to the usage of TBCs in industrial gas turbines. 


\subsection{Materials in a TBC system}

\subsubsection{Top Coat}

The top coating layer in TBCs offers thermal insulation against the hot gases in a gas turbine. It is not difficult to realize that the performance and integrity of the top coat is very critical for the performance of the entire gas turbine as spallation of the top coat will expose the underlying turbine components to the dangerous hot gases at temperatures beyond their melting points. Top coat together with internal cooling (circulating part of the air from the compressor exit through the internal channels of the turbine component) of the components together reduce the temperature of the substrate so that they do not lose their load bearing capabilities. A temperature drop in the top coat can be as much as $100-300{ }^{\circ} \mathrm{C}$ for a coating thickness in the range of $0.1-0.5 \mu \mathrm{m}$ [4]. Naturally, the material for the top coat should have a low thermal conductivity. The thermal expansion coefficient should be close to the thermal expansion of the substrate to reduce the stresses caused by thermal expansion mismatch. The material should also exhibit high temperature phase stability [5].

There have been a lot of materials that have been researched for TBC top coat material. Among them yttria stabilized zirconia, YSZ, is the industry standard TBC material at present. As the name indicates, yttria is added to zirconia to stabilize its phase at high temperature. Phase diagram of yttria-zirconia is shown in Fig. 3. Pure zirconia is allotropic. It exhibits a monoclinic structure till $1170{ }^{\circ} \mathrm{C}$, tetragonal structure in the temperature interval of $1170-2370{ }^{\circ} \mathrm{C}$ and cubic structure up to its melting point at $2690{ }^{\circ} \mathrm{C}$. The phase transformation of zirconia from tetragonal to monoclinic is martensitic and involves a 3-5\% volume increase [5]. This is sufficient to damage the integrity of the coating and is a serious concern. Yttria, when added to zirconia in the range of 6-8 wt.\%, forms a non-transformable tetragonal prime (t') phase [6]. This phase is stable up to $1200{ }^{\circ} \mathrm{C}$, above which the zirconia partitions into yttria poor tetragonal and yttria rich cubic [2,7]. The value of 6-8 wt.\% for $\mathrm{Y}_{2} \mathrm{O}_{3}$ has been arrived from durability rig testing by Stecura [8]. 


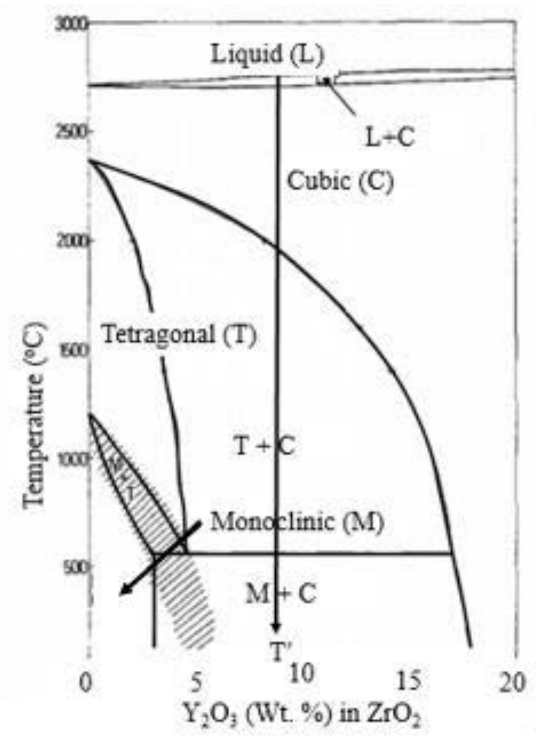

Fig. 3 Phase diagram of $\mathrm{ZrO}_{2}-\mathrm{Y}_{2} \mathrm{O}_{3}$ system. Based on Ref [9]

YSZ has several attractive properties such as low thermal conductivity and high coefficient of thermal expansion [6,10]. It is thermodynamically compatible with the protective thermally grown oxide (TGO). It also exhibits high fracture toughness over 2 MPa.m ${ }^{1 / 2}[11,12]$. All these have made YSZ the preferred choice for top coat material in TBC applications for many decades. With increasing demands on more energy efficient gas turbines, the requirement falls on higher turbine inlet temperatures. YSZ has a functional operational limit of about $1200{ }^{\circ} \mathrm{C}$ and for better performance higher than this temperature, YSZ may have to be substituted with other materials [13]. There are other limitations with YSZ such as sintering at high temperatures and it is susceptible to attack of certain corrosive species. For any new materials to be considered as the potential replacement for YSZ, there are many requirements a material has to satisfy, with thermal conductivity being the foremost.

Before discussing other potential materials for TBC applications, it is worth mentioning about the recently developed nano-structured yttria stabilized zirconia coatings. Nano-YSZ coatings exhibit a bimodal feature consisting of a structure formed by the re-solidification of the agglomerates, that were fully melted in the spray jet, and zones from the incorporation of the semi-molten material [14]. Published research about nano-YSZ shows that these coatings exhibit better life during both thermal shock and thermal cycling tests compared to the conventional YSZ coatings [15-18]. Work by Lima and Marple shows that nano-YSZ coatings have better sintering resistance compared to the conventional YSZ coatings [14]. These coatings also exhibit corrosion resistance superior to the conventional YSZ in the presence of $\mathrm{V}_{2} \mathrm{O}_{5}$ and $\mathrm{Na}_{2} \mathrm{SO}_{4}$ [19]. In spite of all the improvements that nano-YSZ coatings exhibit over the conventional YSZ, the research to further develop these coatings seems to be not as intensive as the research focused on finding alternative materials for replacing the YSZ. This could be due to the upper operating temperature limit of YSZ or that the properties exhibited by other potential TBC materials outweigh these advantages of nano-YSZ. 
In the context of research on TBC materials other than YSZ, several other oxides such as $\mathrm{CaO}$, $\mathrm{MgO}, \mathrm{Sc}_{2} \mathrm{O}_{3}$ and $\mathrm{CeO}_{2}$ have been tested but none of these coatings satisfies the requirement of long term stability of the resulting oxide [5]. Recent research has been focused on pyrochlores of the type, $\mathrm{A}_{2} \mathrm{~B}_{2} \mathrm{O}_{7}$ [20,21]. Pyrochlores, especially $\mathrm{Gd}_{2} \mathrm{Zr}_{2} \mathrm{O}_{7}$, exhibits better thermal insulation (lower thermal conductivity) compared to YSZ [22,23]. Two of the limitations with $\mathrm{Gd}_{2} \mathrm{Zr}_{2} \mathrm{O}_{7}$ are that it is thermodynamically incompatible with alumina (thermally grown oxide) [24] and it has a lower CTE compared to YSZ [25]. This led to the use of multi-layer coatings with YSZ as the inner layer (on top of the bond coat) and gadolinium zirconate coating as the outer layer. It has also been shown that these multi-layer coatings may provide better thermal cycling life compared to single-layer YSZ coatings [26]. These results show that the focus of research on new TBC materials may shift more towards pyrochlores.

\subsubsection{Bond coat}

While the top coat material provides the required thermal insulation, it is essentially transparent to oxygen. In addition, due to the pores and the micro cracks in the top coat, the deposits of corrosive salts can melt and infiltrate the top coat and reach the substrate. The underlying substrate, thus, still needs to be protected against oxidation and corrosion from the hot gases. Typical elements for good oxidation and corrosion resistance are aluminum and chromium respectively. The content of these elements in the substrates are generally not sufficient to impart the required resistance against oxidation and corrosion at elevated temperatures. Increasing the content of $\mathrm{Al} / \mathrm{Cr}$ beyond a certain range will affect the creep strength of the substrate [5]. Therefore, an oxidation resistant metallic coating, known as bond coat, is introduced between the substrate and the top coat.

One of the most common bond coats is of MCrAlX type, where $\mathrm{M}$ stands for either $\mathrm{Ni}$, Co or a mixture of both, $\mathrm{Cr}$ for chromium, $\mathrm{Al}$ for aluminum and $\mathrm{X}$ for any reactive element (yttria is used in a majority of the bond coats). Certain minor elements such as $\mathrm{Si}, \mathrm{Hf}, \mathrm{Re}$ and $\mathrm{Ru}$ may also be added to improve the adhesion of the oxide scale. Bond coat, as the name suggests, improves the bonding between the substrate and the top coat. Oxidation resistance is offered by the formation of a continuous oxide layer, alumina, at the bond coat/top coat interface (discussed in the section below). The microstructure of the bond coat contains $\beta+\gamma / \gamma^{\prime}$ phases along with certain percentages of $\sigma$-phases [27]. A bond coat microstructure with $\beta+\gamma$ phase is shown in Fig. 4a. The dark region in Fig. 4a represents the $\beta$-phase and the bright region represents the $\gamma$-phase. It can be noted that the content of $\mathrm{Al}$ in the $\beta$-phase is higher than in the $\gamma$-phase, see the EDS results in Fig. 4b. The $\beta$-phase, NiAl, with an ordered BCC crystal structure, acts as an $\mathrm{Al}$ reservoir and promotes the growth of alumina and hence is of particular interest. 

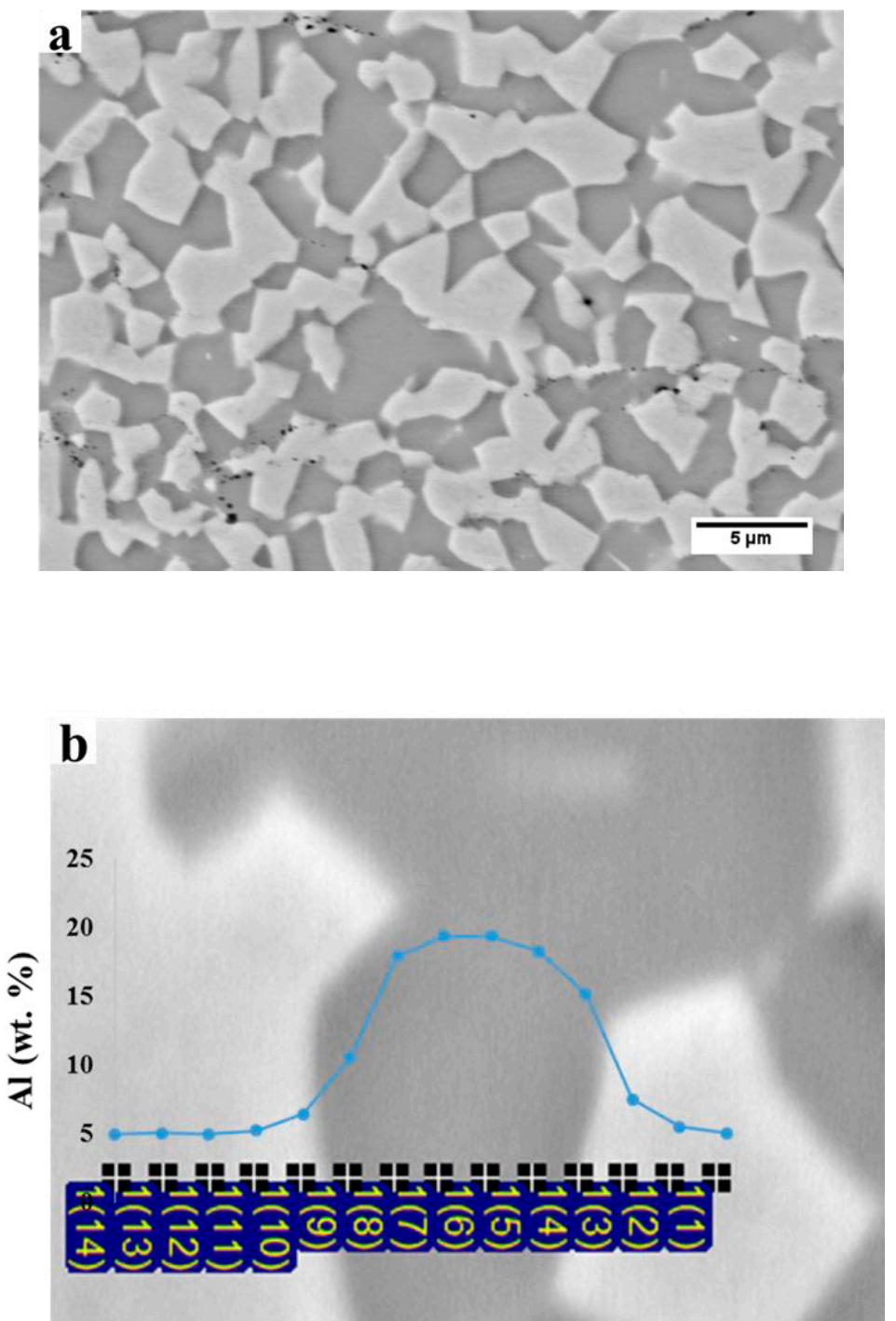

Fig. 4 showing a) $\beta+\gamma$ microstructure in a MCrAIY coating and b) Al content in the $\beta$ and the $\gamma$ phase respectively

\subsubsection{Thermally grown oxide}

Thermally grown oxide (TGO), growing from the bond coat and between the bond coat and top coat interface, is a passive and protective oxide offering protection against oxidation and, to certain extent, corrosion. The property requirements on the oxide layer are that it should be dense, slow growing and have good adherence to the bond coat. Three types of oxides, alumina $\left(\mathrm{Al}_{2} \mathrm{O}_{3}\right)$, chromia $\left(\mathrm{Cr}_{2} \mathrm{O}_{3}\right)$ and silica $\left(\mathrm{SiO}_{2}\right)$, are considered to meet these criteria [28]. However, in practice most high temperature MCrAlY coatings rely on the formation of alumina as the 
protective oxide layer due to the limitations of other two oxides. Chromia can form volatile oxides at higher temperatures and in the case of silica, to form a silica scale, the amount of $\mathrm{Si}$ added to the coating should be relatively high. Also, due to the fact that silicon diffuses fast into the substrate, its interaction with the substrate can deteriorate its properties [28]. The alumina scale is dynamic in the sense that the layer grows by reacting with oxygen when exposed to high temperatures. A typical oxidation sequence involves the formation of transient oxides that grow rapidly until a continuous layer of alumina is formed. The diffusion of oxygen through alumina is very slow and thus the oxidation is slowed down [28]. An aluminum content of 20 wt.\% is required for alumina growth in a $\mathrm{Ni}-\mathrm{Al}$ system [29]. However, with the addition of $\mathrm{Cr}$ to the coating the activity of $\mathrm{Al}$ is increased and alumina can be formed with $\mathrm{Al}$ content as low as 5 wt. \% [29].

The oxidation growth rate follows an Arrhenius type equation [30]

$$
K=k_{o} e^{-Q / R T}
$$

where $K$ is the oxide growth rate constant, $k_{o}$ is a constant, $\mathrm{Q}$ is the activation energy, $\mathrm{T}$ is the temperature (Kelvin) and $R$ is the universal gas constant $(\mathrm{R}=8.314 \mathrm{~J} / \mathrm{mol} . \mathrm{K})$.

During high temperature exposure, for instance $1100{ }^{\circ} \mathrm{C}$, TBCs are considered functional as long as the growing oxide scale is alumina. When a continuous alumina can no longer be formed/maintained, other non-protective oxides, for instance, $\mathrm{NiO}, \mathrm{CoO}, \mathrm{Cr}_{2} \mathrm{O}_{3}$ and $(\mathrm{Co}, \mathrm{Ni})(\mathrm{Cr}, \mathrm{Al})_{2} \mathrm{O}_{4}$ can be formed, replacing the original alumina [27,31-33]. The growth rate of these oxides is higher compared to the growth rate of alumina [32] and will eventually result in the failure of the coating. Fig. 5 shows the cross section of a failed TBC with both the dense alumina and the porous non-protective oxides (spinels).

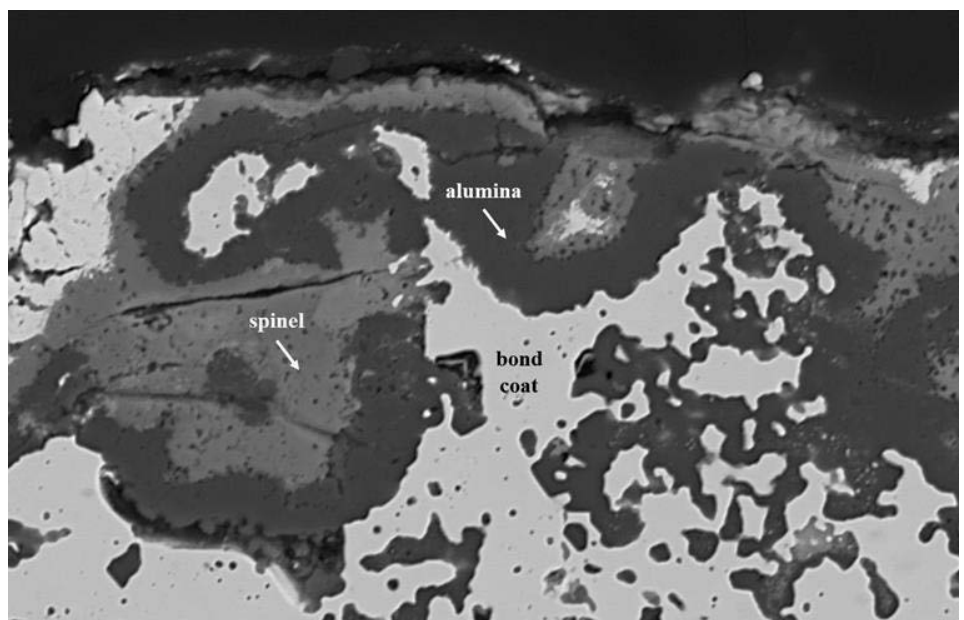

Fig. 5 Cross section of a TBC system showing the protective alumina (dark region) and the non-protective spinels (grey region)

\subsubsection{Substrate}

Substrates (or the base materials) are the actual turbine components over which the above mentioned coatings are deposited. The function of the substrate is to provide the required mechanical, fatigue and creep properties for the application at high temperatures. Currently, Ni- 
based superalloys with more than 10-11 alloying elements are used as the base materials [2]. The strength for these alloys can either come from solution strengthening, as in the case of Hastelloy X, or through precipitation hardening, for instance Inconel 792, by the formation of ordered FCC $\gamma^{\prime}$. The type of hardening mechanism is dictated by the type of alloying elements. In general, precipitation hardened superalloys exhibit higher strength compared to solution strengthened superalloys [29]. Accordingly, the latter superalloys are preferred in more demanding applications in a gas turbine such as turbine blades. More extensive discussion on superalloys can be found in Ref [2].

\subsection{Deposition techniques for TBCs}

Thermal barrier coatings are usually deposited by thermal spraying. Thermal spraying refers to a large group of techniques where the powder particles are heated up till they are molten/semimolten and are deposited on to the sample. Two common industrial techniques used for depositing thermal barrier coatings on gas turbine components are atmospheric plasma spraying (APS) [5] and electron-beam physical vapor deposition (EB-PVD) [5]. Recently, a new thermal spray technique, known as suspension plasma spraying (SPS)[34] has been developed that can produce a columnar structure similar to EB-PVD. The coating deposition parameters and the type of coating technique can have a significant influence on the performance of the TBCs. As APS and SPS are the main coating deposition techniques used in this work, typical microstructural features of APS and SPS coatings are described below.

\subsubsection{Atmospheric Plasma Spraying}

In atmospheric plasma spraying (APS), the plasma is generated in a gas stream using a high frequency direct current. The generated plasma is accelerated out of the nozzle and the power particles that are to be deposited are injected into the plasma. The powder particles either completely molten or semi-molten impact the substrate and get deposited on it. Further details about plasma spraying and its setup can be found in Refs [35,36]. A typical microstructure of top coat and bond coat obtained from atmospheric plasma spraying are shown in Fig. 6a-6c. Fig. 6a, imaged over the as deposited surface, shows the through-splat cracks that are formed when the molten liquid/semi-molten particle solidifies over the already solidified splats. Fig. $6 \mathrm{~b}$ shows the inter-splat cracks and pores in the cross-section of the top ceramic coating. Fig. $6 \mathrm{c}$ shows the inter-splat cracks in the bond coat cross-section. All these features are typical of atmospheric plasma spraying. 

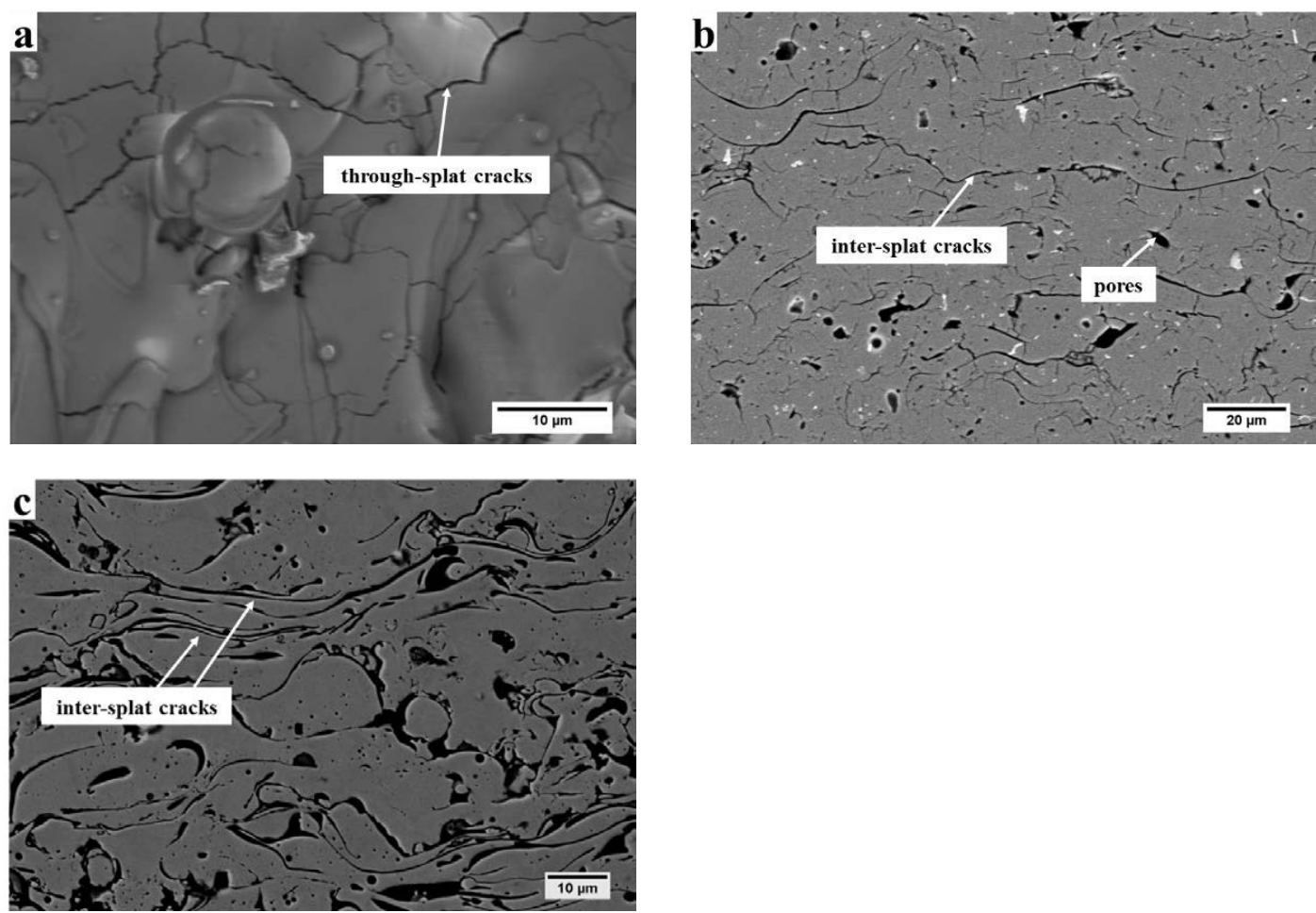

Fig. 6 showing a) typical top view of an APS YSZ coating, b) cross section view of APS YSZ coating and c) cross section of APS MCrAIY bond coat

\subsubsection{Suspension plasma spraying}

Suspension plasma spraying (SPS) is a recently developed technique to obtain coatings with a columnar structure. In this process, a liquid feed stock is used instead of a powder feedstock used in the conventional plasma spraying. The liquid feed stock consisting of particles, generally in the sub-micron ranges, is suspended in a solvent and the spraying is carried out. Further details about the suspension plasma spraying and the formation of columnar structure can be found in Ref [34]. Fig. 7 shows the typical features obtained from the suspension plasma spraying. As can be seen, a columnar type microstructure can be obtained from the SPS technique.

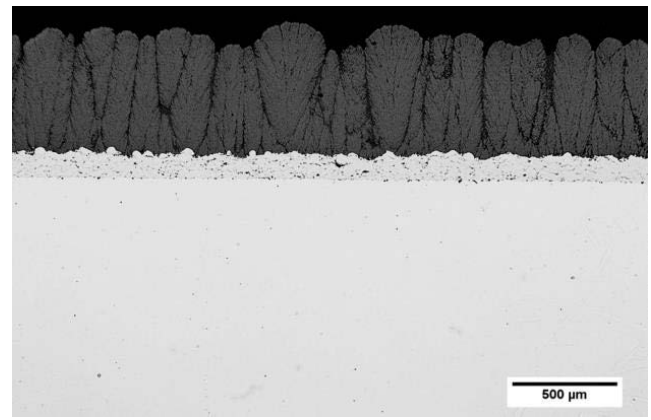

Fig. 7 Cross-section of an SPS YSZ coating with a columnar structure 
The microstructural feature difference between APS and SPS coatings (splat-on-splat structure vs columnar structure) are important as they can significantly influence the lifetime of the coatings during cyclic oxidation. The columnar structure of SPS coatings is expected to provide higher strain tolerance during thermal cycling. On the other hand, during exposure to corrosive environment, the columnar boundaries in the SPS coatings may serve as effective pathways for the molten salts. 



\section{TBCs - Failure Mechanisms}

Thermal barrier coatings (TBCs) are considered to have failed when the coatings no longer satisfy their functional requirements. In general, when the top coat of a TBC spalls off, it is considered to have failed. Failure of TBCs is considered to be both application and system dependent. The type of deposition technique, obtained coating microstructure, and operating conditions as well as environment all influence how damage in TBCs forms and develops. The damage can start to develop in the three TBC constituents, namely bond coat, TGO and the top coat. In most situations it is a combination of different damage processes that occur simultaneously and result in the final TBC failure. The focus of the present research is to understand the failure mechanisms of the TBCs during thermal cycling and corrosion and they are discussed in detail in the sections below. Other failure mechanisms are briefly described.

\subsection{Thermal cyclic tests and typical failure mechanisms}

Thermal cyclic fatigue (TCF) is one of the most commonly conducted laboratory scale experiments that is being used by both the academia and the industries. TCF tests can provide a reliable estimate of the thermal fatigue life of thermal barrier coatings. During the TCF tests in this work, the samples are placed inside a furnace where they are thermally cycled from 100 ${ }^{\circ} \mathrm{C}-1100{ }^{\circ} \mathrm{C}$ with a dwell time of $1 \mathrm{~h}$ at $1100{ }^{\circ} \mathrm{C}$. Forced cooling to roughly $100{ }^{\circ} \mathrm{C}$ takes place using compressed air in about $10 \mathrm{~min}$. The heating + dwell time + cooling time together constitute one TCF cycle.

During a TCF test, the samples either move to the cooling stage where they are cooled by the compressed air and the furnace remains stationary or the furnace moves away and the cooling system comes atop the ceramic plate and the samples are cooled. The latter set up has been used in the present research and the schematic of it is illustrated in Fig. 8.
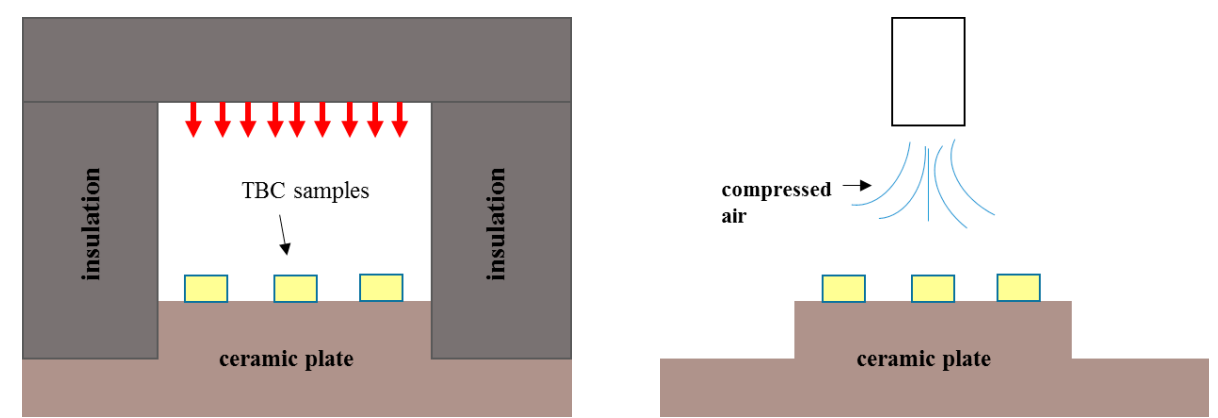

Fig. 8 Schematic illustration of a thermal cycling test rig 
There are certain limitations with the TCF testing of thermal barrier coatings. The conditions during TCF are isothermal i.e. the entire sample is at the same temperature compared to an actual turbine operation where the thermal barrier coatings are primarily designed to provide thermal gradient. Ranjbar-Far.et.al [37] have shown that having homogenous temperature may accelerate failure and reduce the lifetime of the coatings. The testing time can last over a month depending upon the quality of the coatings and it is not possible to obtain a quick result with this type of test. Also it is considered that the lifetime of the TBCs during thermal cycling is related to the TCF rig design. Furthermore, changing the substrate geometry will influence the thermal fatigue life of the TBC system [38].

A conventional way to assess the failure of the TBCs during TCF is identifying the time when the spallation of the top coat reaches $20 \%$. Though the failure criterion is straightforward, the underlying mechanisms leading to failure can be significantly different. From the literature, three different failure modes are usually observed; a) white failure, b) black failure, c) mixedtype failure. White failure refers to the complete failure within the top coat, black failure refers to the failure in the TGO layer and mixed-type failure, as the name indicates, refers to failure partly in the top coat and partly in the TGO [39]. Multiple factors could contribute to the final failure of the TBCs during thermal cycling and they are discussed below.

Continuous bond coat oxidation is considered to be the most important cause of TBC failure. During the high temperature dwell time of TCF cycles, the bond coat is oxidized and a thermally grown oxide (TGO) layer grows at the bond coat/top coat interface. This oxide layer, typically alumina, protects the underlying bond coat and the substrate from rapid oxidation, as discussed in Section 2.1.3. With longer exposure times at high temperature, the thickness of the oxide layer is increased. Two types of stresses can develop in a TGO. The first one, known as TGO growth stress, is related to the conversion of the high density metal into low density oxide. The second one arises because of the mismatch in the coefficient of thermal expansion (CTE) between the bond coat and the TGO. The total residual stresses in the TGO is then the sum of the TGO growth stresses and stresses due to CTE mismatch. The magnitude of the growth stresses for alumina at room temperature is approximately $-1 \mathrm{GPa}$ and they constitute roughly $30 \%$ of the total residual stresses in the TGO [5]. Once the oxide thickness reaches a critical value (generally considered to be in the range of 6-10 $\mu \mathrm{m}$ ) the oxide layer spalls off and this marks the end of the coating life.

The formation of non-protective spinel oxides can accelerate TBC failure. When the bond coat is oxidized, resulting in the formation of alumina $\left(\mathrm{Al}_{2} \mathrm{O}_{3}\right)$, local depletion of $\mathrm{Al}$ takes place. In the case of bond coats with low aluminum content this can happen in the early stages of the TCF life. Since the bond coat acts as an aluminum reservoir and promotes the continuous growth of alumina, it is important to retain a certain amount of $\mathrm{Al}$ which is critical to alumina formation. Local depletion of $\mathrm{Al}$ will result in the oxidation of other elements in the bond coat such as $\mathrm{Ni}$, Co and $\mathrm{Cr}$. These oxides, spinels, are not protective and have much higher growth rate compared to alumina. This results in further oxidation of the bond coat and also increases the residual stresses, eventually causing spallation of the top coat.

Inter-diffusion between the bond coat and substrate is another mechanism that can affect the TBC's life. Due to the high temperature exposure and difference in the activities of $\mathrm{Al}$ in the bond coat and in the substrate, Al tends to diffuse from the coating into the substrate, a 
phenomenon known as inter-diffusion. Fig. 9 shows the Al activity, calculated from ThermoCalc, for a few commercial substrate and coating systems. As can be seen, the activity of $\mathrm{Al}$ is always higher in the coatings compared to the substrates and, therefore, the difference will result in $\mathrm{Al}$ diffusion into the substrate. Inter-diffusion of $\mathrm{Al}$ from the coating into the substrate may be avoided by selecting the substrate-coating system in such a way that the difference in their activities is minimum. Inter-diffusion of $\mathrm{Al}$ results in the depletion of the $\beta$ phase ( $\mathrm{Al}$ reservoir) in the coating. Faster Al depletion may promote the formation of spinels in the coating and eventually reduce the overall thermal fatigue life of the TBC system. Eriksson et.al have found a significant difference in the TCF life time for the same TBC coatings but on two different substrates [40]. Apart from the Al inter-diffusion, diffusion of other elements between the coating and the substrate is also undesirable as the elements that give the properties and functionality for coating/substrate tend to diffuse out. Outward diffusion of refractory elements from the substrate into the coating can change the TGO growth rate and reduce the oxidation resistance of the coating [41].
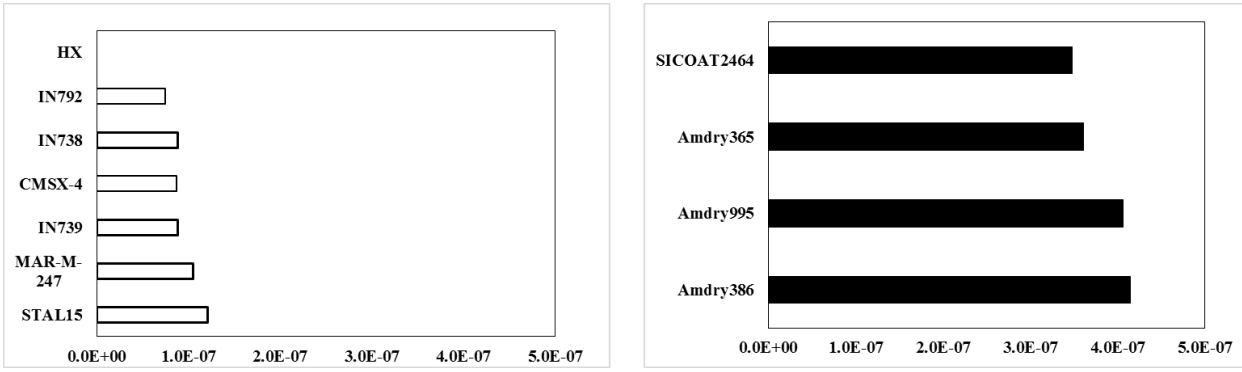

Fig. 9 Activity of $\mathrm{Al}$ in different commercial substrates (left) and MCrAIY coating systems (right)

The mismatch in the coefficient of thermal expansion between the top coat and the substrate is also one of the factors that may contribute to the damage during TCF. During the cooling stage in the TCF tests, due to the difference in CTE, thermal stresses start to build up in the ceramic coating. Although these stresses are an order of magnitude lower than the residual stresses in TGO [4] they may still contribute to the coating damage. To study the failure due to the CTE mismatch between the top coat and the substrate, thermal shock tests, also known as burner rig tests [42] are conducted. Here, the heating and cooling rates are usually much higher and the dwell time at high temperature is very short compared to the thermal cycling tests. Due to very short dwell times, the TGO growth is very limited and hence the contribution to the failure during thermal shock tests mainly comes from the thermal stresses due to the CTE mismatch between the top coat and the substrate [43].

Sintering of the top coat which results in an increase in the thermal conductivity and elastic modulus is also one of the factors that could contribute to the TBC failure. Atmospheric plasma sprayed YSZ coatings have micro cracks, fine pores and irregular shaped pores from the deposition process that lower both the thermal conductivity and stiffness of the top coat. During exposure at high temperature, sintering of micro cracks, fine pores and spheroidization takes place. This, in turn, increases the thermal conductivity and the elastic modulus. Increased thermal conductivity is not desirable as the thermal gradient across the coating is reduced and the coatings lose their functionality (while relevant for an actual turbine application it is not relevant for TCF type testing as the entire system is at a constant temperature). Increase in the 
elastic modulus will reduce the strain compliance of the coating and thereby increase the thermal stresses due to CTE mismatch. This will reduce the lifetime of the thermal barrier coatings.

Other factors, for tests conducted at higher temperatures of about $1200{ }^{\circ} \mathrm{C}$, include partitioning of the tetragonal prime phase of zirconia into yttria rich-cubic and yttria poor-tetragonal zirconia. During cooling tetragonal zirconia undergoes a martensitic phase transformation with $3-5 \%$ volume change resulting in cracks in the coating [44].

For a good TCF life, the desired properties of a TBC can be summarized as, low thermal conductivity and low elastic modulus for the top coat, high Al containing bond coat and a substrate with relatively high aluminum activity.

\subsection{Hot corrosion tests - Failure mechanisms}

Corrosion induced damage is one of the common problems observed in gas turbine engines [45]. The source for the corrosive species is either the fuel (contains V and S) or intake air which contains sodium chloride $(\mathrm{NaCl})$. These corrosive species, at the high temperature inside the turbine, react and form sodium sulfate $\left(\mathrm{Na}_{2} \mathrm{SO}_{4}\right)$ and vanadium pentoxide $\left(\mathrm{V}_{2} \mathrm{O}_{5}\right)$. Corrosive attack of either $\mathrm{V}_{2} \mathrm{O}_{5}$ or a mixture of $\mathrm{Na}_{2} \mathrm{SO}_{4}$ and $\mathrm{V}_{2} \mathrm{O}_{5}$ is rather severe. Pure $\mathrm{Na}_{2} \mathrm{SO}_{4}$ does not directly react with YSZ layer in a TBC although its infiltration into pores and cracks may eventually cause thermo-mechanical damage [46]. There has been considerable research on the corrosion behavior in thermal barrier coatings either in the presence of $\mathrm{Na}_{2} \mathrm{SO}_{4}$ and $\mathrm{V}_{2} \mathrm{O}_{5}$ or only $\mathrm{V}_{2} \mathrm{O}_{5}[19,47-54]$. The tests reported in the literature have been conducted from $700{ }^{\circ} \mathrm{C}$ to about $1050{ }^{\circ} \mathrm{C}$ using different salt concentrations, with a majority of the tests focused on YSZ thermal barrier coatings. Limited research on the corrosion mechanism of other top coat materials such as gadolinium zirconate [48,49,55], ceria-stabilized zirconia [56-58], titaniastabilized zirconia [58], scandia and yttria co-stabilized zirconia [59] and zirconia-alumina [54] have been reported as well.

The general corrosion mechanism at temperatures of about $900{ }^{\circ} \mathrm{C}$ or above for YSZ thermal barrier coatings is that the molten vanadium pentoxide or sodium meta vanadate $\left(\mathrm{NaVO}_{3}\right)$, a reaction product of sodium sulphate and vanadium pentoxide, attacks the zirconia stabilizer, yttria, and forms $\mathrm{YVO}_{4}$. Fig. 10 (left image) shows a typical top view of the corrosive products, $\mathrm{YVO}_{4}$ with a rod like structure, and the right image shows the cross sectional view of $\mathrm{YVO}_{4}$ formation along the micro cracks of the top coat. Leaching of yttria and formation of $\mathrm{YVO}_{4}$ will result in the dangerous phase transformation of zirconia from tetragonal to monoclinic with a 3-5\% volume change. In addition, there are also growth stresses associated with $\mathrm{YVO}_{4}$ formation which together with the phase transformation stress result in the corrosion induced damage. 

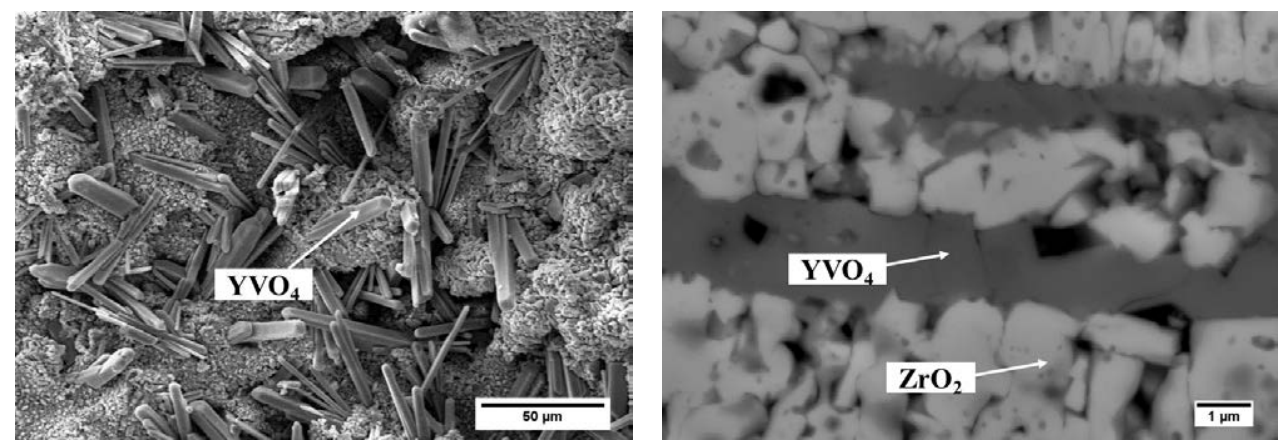

Fig. 10 Typical top (left) and cross-sectional (right) view of the corroded YSZ coating

The other kind of corrosion tests commonly reported are with either a mixture of $\mathrm{Na}_{2} \mathrm{SO}_{4}$ and $\mathrm{NaCl}$ [60-63], a mixture of sodium sulfate $\left(\mathrm{Na}_{2} \mathrm{SO}_{4}\right)$ and potassium sulfate $\left(\mathrm{K}_{2} \mathrm{SO}_{4}\right)$ [64], or salts in the presence of sulphur [64]. Corrosion tests in the presence of water vapor have also been reported [65]. Corrosion tests with these type of salt mixtures are mainly aimed at inducing corrosive attack in the bond coat and have been conducted with both TBCs and overlay coatings. These tests, in general, are not as aggressive as the tests with vanadium pentoxide. The general corrosion mechanism here is that the corrosive salts attack the protective oxide at bond coat/top coat interface by dissolving it and forming non-protective compounds. With increased exposure time, the penetration depth of the salts increases and eventually will result in the failure of the coating.

\subsection{CMAS Corrosion}

For gas turbines operating above $1200{ }^{\circ} \mathrm{C}$, failure can occur by the deposits of calciummagnesium-aluminum-silicate, referred to as CMAS [66-69]. CMAS deposits on the turbine components are more likely to occur in gas turbines operating in areas close to the deserts. The ingested sand particles (CMAS deposits) are usually benign when they are in solid form, however, at high temperatures, they melt (approximately at $1240{ }^{\circ} \mathrm{C}$ [70]) and infiltrate the coating. During cooling the molten particles solidify and modify the thermo-mechanical properties of the coating and increase its susceptibility to spallation [70].

\subsection{Erosion and Foreign Object Damage}

Erosion of the top coat occurs due to the impact of the abrasive particles on the coating surface. Erosion is usually caused by small particles whereas foreign object damage is caused by large particles. Both Erosion and FOD are one of the commonly observed phenomenon during the operation of a gas turbine.

\subsection{Other factors related to TBCs deposition}

Some of the other factors that influence the overall life time of the TBC are a proper choice of process parameters (to achieve optimum interface roughness between the bond coat and the top coat, good porosity range) and a good preparation of substrate surface prior to bond coat deposition to have a good bonding between them. 



\section{Modelling}

Modelling, as a tool, can be used for advancing our understanding of the behavior of the coatings at high temperature or when conducting extensive experiments may be impractical. Due to the complex nature of multiple failure mechanisms that occur during the operation of a TBC (see Chapter. 3), developing an universal model that can address all the issues is not possible. A reasonable way in model development is to focus on each failure mechanism separately. Although the capabilities of such models are limited, they can, nevertheless, provide the direction to optimize the design of the coatings.

The modelling work carried out in this study has been focused on two different failure mechanisms in thermal barrier coating systems: elemental inter-diffusion between the substrate and the bond coat and modelling of crack growth due to bond coat oxidation and TGO formation during thermal cycling. For studying the inter-diffusion, the commercial software DICTRA, from Thermo-Calc, has been used. For modeling the crack growth, ABAQUS, has been used. Both the models are described below.

\subsection{Inter-diffusion modelling}

DICTRA is a simulation software used for predicting the diffusion of elements in multicomponent alloys [71]. The simulations are based on both the kinetic and thermodynamic data of the elements. Using DICTRA, diffusion behavior of elements between the coating and substrate [72,73] as well as the phase fractions [74] can be predicted for different temperatures and diffusion times.

To study the inter-diffusion of elements between MCrAlY and substrate at high temperatures, surface oxidation in MCrAlY has to be considered as these two happen simultaneously. An oxidation-diffusion model developed by Yuan and Eriksson $[75,76]$ has been used in this work. In the model, the elemental oxidation in MCrAlY is limited to only $\mathrm{Al}$ and has been addressed by coupling DICTRA with Matlab. An empirical model was used to simulate the loss of $\mathrm{Al}$ in the surface due to oxidation. The model works in an iterative way where during each iteration, oxidation and inter-diffusion between the coating and the substrate are carried out for a small time step. Al is removed from the MCrAlY surface based on the TGO growth law. The diffusion part is handled by DICTRA while the oxidation part is handled by Matlab. The iterations continue until the $\mathrm{Al}$ level falls below a critical level (set by the user). More comprehensive description of the model can be found elsewhere [75,76]. From this model, diffusion profiles for various elements in the substrate/coating, phase fractions of $\beta$ and $\gamma / \gamma^{\prime}$ phases can be obtained. For obtaining the coating life criterion several different approaches can be used, for instance a complete $\beta$-phase or $\gamma^{\prime}$-phase depletion criterion, depending on the requirement. This model in general showed a good agreement with the isothermal oxidation tests on overlay 
coatings. The model can help in the selection of different coating-substrate combinations without the need for extensive experimental work. However, it has to be noted that the accuracy of DICTRA simulations and this model is very dependent on the accuracy of the thermodynamic and kinetic databases used. Furthermore, as the purpose of the model was to study only inter-diffusion effects other factors that contribute to the TBC failure were not considered.

\subsection{Crack growth modeling}

Fatigue cracks grow in thermal barrier coatings when the coatings experience thermal cycling. When an aero-engine starts or stops, during take-off, flight and landing the temperature increases/decreases leading to thermal cycling or when a land based gas turbine is shut down for maintenance the turbine parts cool down and again the coatings experience thermal cycling. The start/stop requirements for an aero-engine and a land based gas turbine are largely different with the latter having fewer start/stop cycles. This means, for land based gas turbines, the coatings are exposed to higher temperatures for much longer duration and bond coat oxidation and TGO growth are very important. Any model developed to simulate the crack growth has to take into account the $\mathrm{BC} / \mathrm{TC}$ interface roughness and TGO growth rate as the failure in this case is expected to be at or near the $\mathrm{BC} / \mathrm{TC}$ interface.

Previous models in the literature, for instance by Rabiei and Evans [77], focused on the critical TGO thickness. The model by DeMasi [78] considered the effect of a strain cycle through a Coffin-Manson like expression shown in Eq. (2).

$$
N=A\left(\frac{\Delta \varepsilon_{p}}{\Delta \varepsilon_{t}}\right)^{-b}
$$

where $\Delta \varepsilon_{p}$ is the plastic strain, $\Delta \varepsilon_{t}$ is the single cycle failure strain and is a function of the TGO thickness, $\mathrm{N}$ is the cycles to failure and $\mathrm{b}$ is a constant.

One of the limitations with this model was the inclusion of plastic strain which may not be applicable to ceramic coatings. In addition, the model was not based on a micro-mechanical delamination process [79]. A new life model was developed by Jinnestrand, Brodin and Sjöström $[79,80]$. It addressed the evolution of micro-mechanical delamination process which was assumed to be more suitable for land based gas turbines. This model has been used as reference in this work. The basis for the model was to relate the crack growth measurements to the calculated stress intensity levels. The bond coat surface was idealized as a sine wave with certain amplitude and wavelength. Cracks were assumed to start from the peak and propagate towards the valley following the interface, and it was considered sufficient to study the crack growth in a least representative cell, consisting of a peak and a valley. A mixed-mode crack growth was suggested, according to the modified Paris' law shown in Eq. (3).

$$
\frac{d D}{d N}=C(\lambda \Delta \mathrm{G})^{n}
$$

Where $\mathrm{D}$ is the normalized interface damage $(0<\mathrm{D}<1), \mathrm{N}$ is the number of cycles, $\mathrm{C}$ and $\mathrm{n}$ are fitting parameters, $G$ is the energy release rate, $\lambda$ is a function involving $K_{I}$ and $K_{I I} . K_{I}$ and $K_{I I}$ are the stress intensity factors in mode I and II respectively. 
$\lambda$ is given by the expression in Eq. (4)

$$
\lambda=1-\left(1-\lambda_{o}\right)\left(\frac{2}{\pi} \tan ^{-1}\left(\frac{\Delta K_{I I}}{\Delta K_{I}}\right)\right)^{m}
$$

where $\lambda_{o}$ and $\mathrm{m}$ are the fitting parameters. The total fatigue life is then obtained by numerically integrating Eq. (3).

This model considered the possibility of three type of cracks growing along the interface ;cracks growing along the TGO/BC interface (interface cracks), denoted as length ${ }^{\text {TGO }}$. Cracks growing in the top coat along the TGO/TC interface but at a certain distance from the interface (ceramic cracks), denoted as length ${ }^{T C}$. Cracks growing partly in the TGO and partly in the top coat (kink cracks), denoted as length $\boldsymbol{k}^{\text {kink }}$.

And the damage (D) was defined as

$$
\mathrm{D}=\frac{\sum_{\mathrm{i}} \text { length }_{\mathrm{i}}^{\mathrm{TGO}}+\sum_{\mathrm{j}} \text { length }_{\mathrm{j}}^{\mathrm{TC}}+\sum_{\mathrm{k}} \text { length }_{\mathrm{k}}^{\text {kink }}}{\mathrm{L}}
$$

where $\mathrm{L}$ is the total length of the interface where the crack lengths were measured. Their unpublished work showed that the interface crack growth, along TGO/BC, as the basic mechanism of crack growth. In the present work, this model was modified by adding more crack growth paths in consistent with the experimental observations from the TCF tests. To further understand the growth direction, and to study whether the growth direction of cracks can have influence on the coatings' lifetime, several types of possible crack growth types were identified. The different crack growth paths considered in this work, shown in Fig. 11a-h, were modelled in ABAQUS. More details about the current modelling approach can be found in Paper I. 

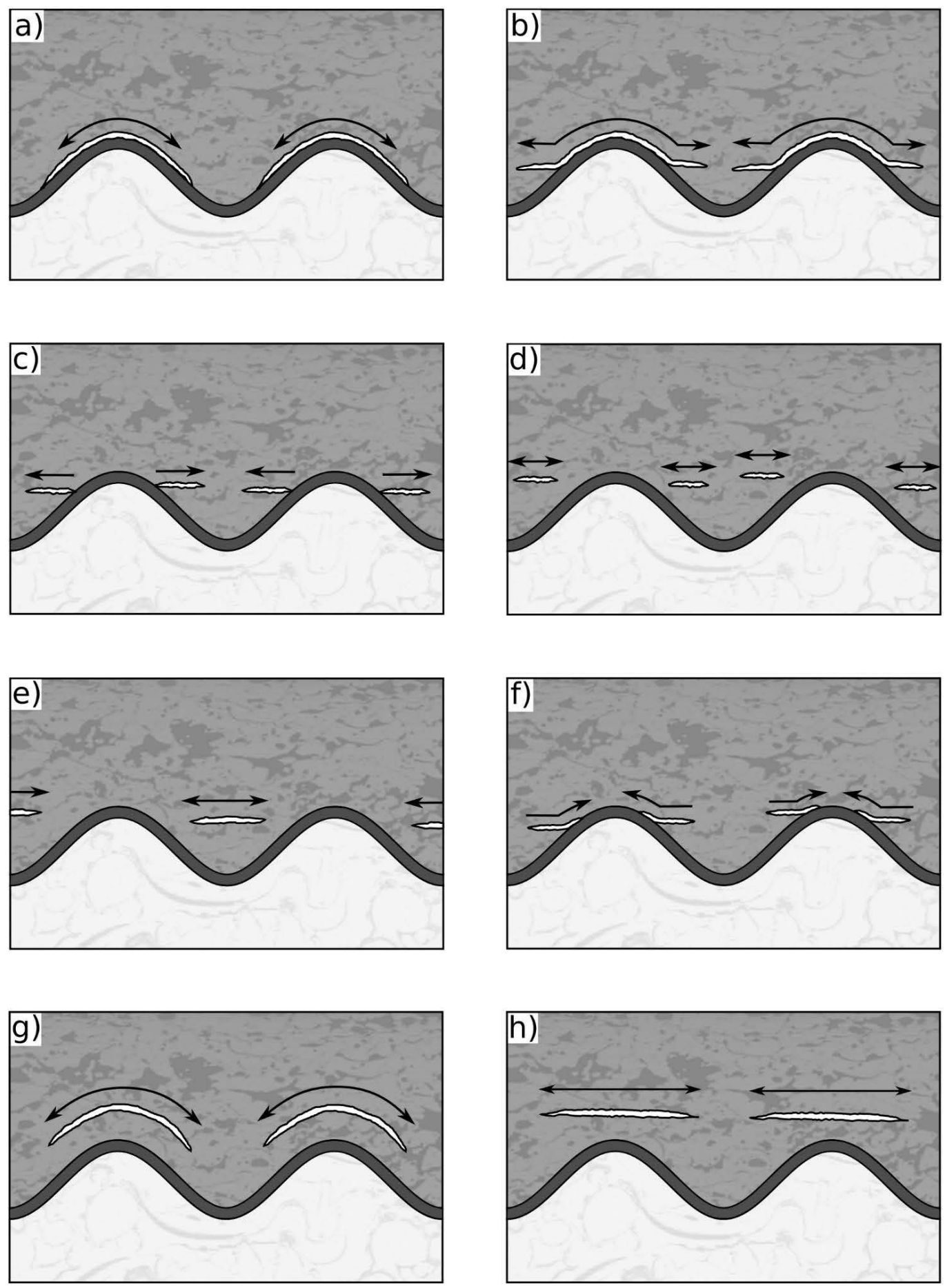

Fig. 11a-h shows different crack growth paths that could contribute to TBC failure [81] 


\section{Experimental Characterization}

\subsection{Sample preparation}

Metallographic sample preparation for thermal barrier coatings is different from the sample preparation for metals. Preparing TBCs for microscopy can be challenging due to the reasons given below.

1. Particles from the ceramic layer, known as pull-outs, tend to come out of the coating and may scratch the surface. Apart from resulting in additional scratches in the sample, the main problem with the pullouts is that they make the ceramic layer appear more porous than it is. As the coating properties are considered to be significantly dependent on porosity, inaccurate measurement of porosity can result in misinterpretation of the coating properties.

2. The interface between the thermally grown oxide (TGO) and the ceramic coating becomes weak especially after thermal cycling. The weak interface can easily be damaged during specimen polishing and it would be very difficult to ascertain if the damage is either process/testing induced or polishing induced.

To mitigate the damage in the TBC system during polishing, the sample is infiltrated with a low viscosity epoxy resin under vacuum. Epoxy infiltration, when properly done, can infiltrate up to depths of $1500 \mu \mathrm{m}$. Epoxy infiltrating into the cracks and pores can reduce the extent of damage during grinding/polishing. Any damage introduced during the specimen preparation can be easily identified as there would be no epoxy in those affected areas.

After epoxy infiltration, the samples are cut to reveal the cross-section. Rough grinding is carried out initially to remove the effects of cutting. Rough grinding is done with discs of grit sizes 120, 220 and 600. Fine grinding is later carried out with diamond abrasives of sizes 15 $\mu \mathrm{m}, 9 \mu \mathrm{m}, 6 \mu \mathrm{m}, 3 \mu \mathrm{m}, 1 \mu \mathrm{m}$ and $0.25 \mu \mathrm{m}$ on cloths. Final polishing is done with colloidal silica polishing suspension.

The samples after polishing need to be coated either with carbon or gold to reduce the charging of the ceramic for analyses in SEM.

\subsection{Porosity Measurement}

Porosity has a pronounced influence on several coating properties such as thermal conductivity [82], elastic modulus [83], fracture toughness etc. Accurate measurement of porosity is thus important to understand the behavior of the coatings. For measuring the porosity in a particular coating using an image analysis software such as ImageJ[84], the first step is to distinguish the actual pores from the pull-outs, which can be done in optical microscope. Regular pores appear 
"green" under optical microscope after infiltration due to the presence of epoxy in the pores as illustrated in Fig. 12. As pull-outs are caused due to polishing, they appear black. It has to be noted that there could be instances of closed porosity where epoxy infiltration is not possible and they would appear similar to pull-outs. With the conventional porosity of TBCs around 10$15 \%$, the amount of closed porosity can be assumed to be relatively low. The same principle can be used to separate interface cracks introduced due to testing from the cracks introduced due to polishing.

It is difficult to distinguish the pull-outs from regular pores in a scanning electron microscope (SEM) because epoxy has a low atomic number relative to the ceramic material in the coating and it results in low signal and hence a dark appearance of the filled pore [85]. Unfilled pores or pull-outs also have low signal and hence difficult to discern from the epoxy filled pores.

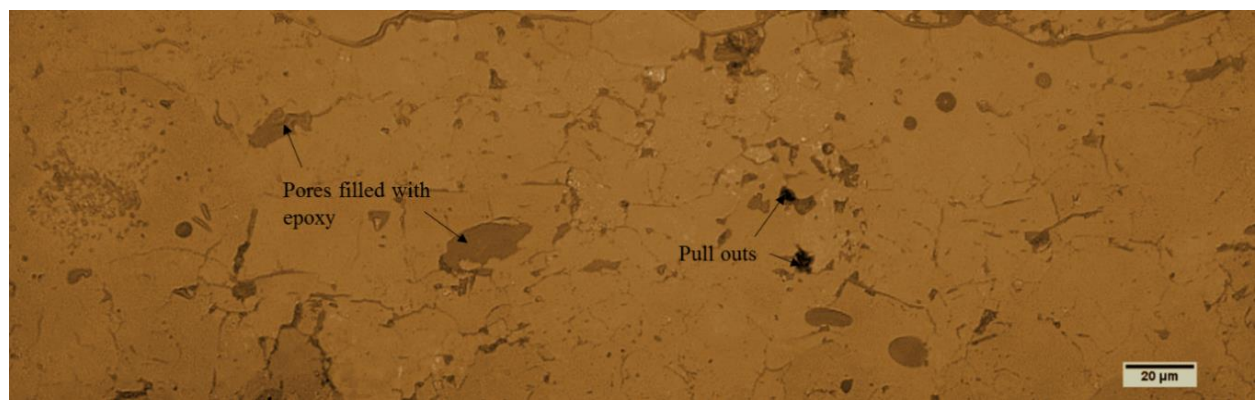

Fig. 12 LOM image shows the cross section of TBC microstructure with epoxy filled pores and pull-outs

For porosity measurement with image analysis, a good contrast between the ceramic coating and the epoxy filled pore is essential. Although the optical microscope investigation can be useful in identifying the regions with minimal or no pull-outs, SEM can provide a good contrast between the pores and the ceramic material due to the large difference in the atomic number between them. Using a threshold algorithm in image analysis, the area of regions that appear "black (pores)" and "bright (ceramic material)" is measured and the area fraction gives an estimate of the porosity. To get reliable estimate of porosity, at least 25-30 SEM images need to be taken. In the present research, all porosity measurements were done using ImageJ.

Other methods to measure porosity include water impregnation, mercury porosimetry and point counting. In water impregnation technique, a free standing coating is immersed in water under vacuum to allow infiltration of water into the coating pores. Measuring the weight of the coating before and after immersion can give the estimation of the coating porosity. In mercury porosimetry technique, a free standing coating in vacuum is infiltrated with mercury by external pressure. Total porosity can be estimated by the total amount of mercury infiltrated into the coatings [86]. In point counting method a test grid is superimposed over the micrograph and the number of test points falling within the constituent of interest are counted and divided by the total number of grid points yielding a point fraction [87].

\subsection{Scanning electron microscopy}

Scanning electron microscopy (SEM) is a powerful microscopy technique that enables both characterization and observation of materials from low to high magnifications. The SEM used 
in the present research is a SU-70 from Hitachi, Japan. The electron microscope is equipped with secondary electron (SE) detector, backscatter electron (BSE) detector and energy dispersive X-ray spectroscopy (EDS) among others. The function of each detector is briefly described below.

\subsubsection{Secondary electron detector}

Secondary electron (SE) detector is used for detecting secondary electrons which are formed due to the inelastic scattering of the beam electrons. Secondary electrons are defined purely on the basis of their kinetic energy, and all electrons emitted below $50 \mathrm{eV}$ are considered to be secondary electrons [88]. Secondary electrons contain information about the topography of the sample. Due to the carbon coating on the ceramic samples, SE mode is not often used because of the appearance of the carbon particles in the cross section. Further details of secondary electrons can be found in Ref [88].

\subsubsection{Back scatter electron detector}

Backscatter electron (BSE) detector is used for detecting high energy backscatter electrons. The BSE mode primarily offers atomic number contrast due to the local differences in the composition. BSE mode is the preferred mode of imaging when taking images for porosity analysis as very good contrast can be obtained because of the high difference in the atomic numbers of the ceramic and the epoxy. Further details about back scatter electrons can be found in Ref [88].

\subsubsection{Energy Dispersive X-ray Spectroscopy}

Energy Dispersive X-ray Spectroscopy (EDS) technique has been used in this research to obtain the coating composition in the as-sprayed state, composition of the coating after high temperature exposure to understand the diffusion of various elements to/from coating/substrate. EDS mapping of the coating provides the qualitative information about the different elements present in the coating.

The ability of EDS to detect elements comes from the fact that each element has a unique atomic structure and that results in the emission of characteristic X-rays unique to a particular element. When the beam electrons interact with the specimen, some electrons in the specimen's elements are knocked out and this leads to a vacancy. Vacancies are then filled by electrons from other shells resulting in the emission of characteristic X-rays. These X-rays are then detected by the EDS detector. Further details about EDS can be found in Ref [88]. It has to be noted that while EDS can provide elemental composition, any element with atomic number lower than 8 is difficult to detect. Furthermore, elemental detection becomes difficult if peaks of two elements overlap. Generally, EDS has a spectral resolution limit of $160 \mathrm{eV}$ and an elemental detection limit of $0.1-0.5 \%$. To solve the problem in detecting elements with low elemental concentration and to resolve overlapping peaks in EDS, another technique known as Wavelength Dispersive X-ray Spectroscopy (WDS) can be used. Here, the wave lengths of the characteristic X-rays and not the energies are measured and that results in significantly high spectral resolution of 2$10 \mathrm{eV}$.

\subsection{Video Monitoring}

Visual inspection of the samples by video recording, using a commercial grade camera, can provide information on damage development during TCF testing. For this work, a video camera 
is set up in such a way that during the start of each cooling cycle, the TCF furnace sends a signal directly to the camera to trigger automatic recording for the first 29 seconds of the cooling cycle. A schematic sketch showing the position of the video camera is shown in Fig. 13.

The principle behind the damage detection is that the delaminated regions of the sample under inspection cool down faster compared to the regions that are still intact. Due to the faster cooling relative to the undamaged regions, the color of the coating appears grey where delamination has taken place. For the intact regions of the coating, the color will be bright red. This is illustrated in Fig. 13 where region 1 in grey shows delaminated layer, 2 shows the still intact region, 3 is the spalled region of the coating. The image to the right shows a perfectly intact coating to the substrate.

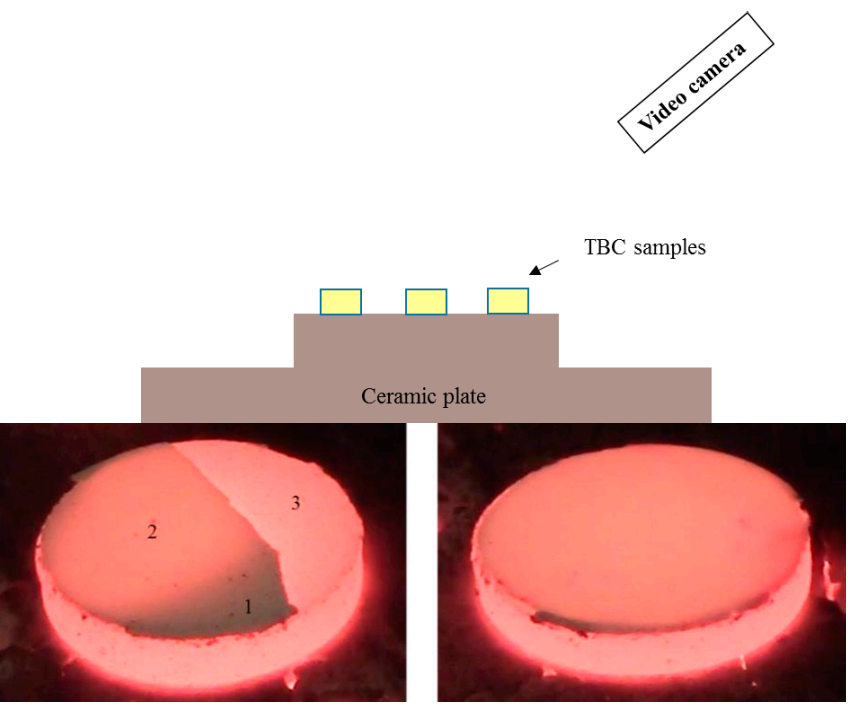

Fig. 13 schematic illustration of the video camera set-up and the appearance of the samples during cooling as observed from the video camera

The damage observed from the video camera is then estimated by measuring the delaminated and the spalled regions as "damaged area" in pixels. Dividing this by the total area in pixels gives the damage development at that particular time.

Another method to study damage development during thermal cycling is by interrupted testing. Interrupted tests refer to stopping the test at specific time intervals, but always before the final failure of the sample. Cross-section analysis of the interrupted test samples can provide information on damage development at various stages before final failure.

From the above mentioned two methods, the use of video monitoring technique is advantageous due to the fact that damage monitoring is continuous and it is also a non-destructive method. 


\section{Summary of appended papers}

In this chapter, the answers to the research questions in section 1.2 are discussed in the form of scientific publications.

\section{Paper 1: A study of damage evolution in high purity nano TBCs during thermal cycling: A fracture mechanics based modelling approach}

Sintering of the top coat at high temperatures and thermal fatigue are one of the commonly observed phenomena in thermal barrier coatings. To resist sintering, a new high purity nano yttria stabilized zirconia has been developed and its damage evolution during thermal cycling fatigue tests is the focus of this paper.

Thermal cycling tests on APS sprayed high purity nano yttria stabilized zirconia (YSZ) thermal barrier coating was conducted at $100{ }^{\circ} \mathrm{C}-1100{ }^{\circ} \mathrm{C}$. The dwell time was $1 \mathrm{~h}$ at $1100{ }^{\circ} \mathrm{C}$. The bond coat and the substrate used in the study were Amdry 365-2 and Hastelloy X respectively. A video camera was set up to extract the information on damage development continuously during the duration of the experiment. The TBC samples showed a lifetime of about 580 cycles.

Cross-section analysis of the failed samples revealed a mixed-type failure and a more detailed analysis of the interrupted TCF test samples revealed that the cracks propagated parallel to the substrate/bond coat interface. The majority of the coating damage had occurred towards the end of the coating life. Observations on the cross sections of the interrupted samples showed the presence of different crack types (cracks propagating only in the top coat close to the TGO/ TC interface, cracks propagating partly through the TGO and partly through the TC, cracks propagating along the TGO/TC interface, cracks propagating along TGO/BC interface etc.). Of all these crack types, the cracks propagating partly in the top coat and partly in the TGO were the most frequently observed and to a certain extent cracks propagating in the top coat close to $\mathrm{TGO} / \mathrm{TC}$ interface.

A finite element model was then used to model different crack growth paths to identify the most probable crack growth mechanism that results in the final failure. A fracture mechanics based approach was used where the rate of crack propagation was explained with the stress intensity factors. The simulation results indicated that as long as the crack remained in the top coat, its stress intensity factors were low and the crack propagation was slower. When the crack reached the TGO/TC interface, the stress intensity factors increased and the crack propagation became faster.

In light of the results from the modelling and with respect to the experimental observations, the most likely failure mechanism was proposed for the nano-structured YSZ thermal barrier coatings during TCF. The cracks initially initiated from defects located in the top coat in the 
region between the bond coat/ top coat interface peaks. The cracks grew slowly in the top coat parallel to the interface. Fast growth of these cracks occurred when they reach the TC/TGO interface. This later led to crack coalescence and eventually caused failure.

Crack-lengths were measured from the interrupted test samples, at different TCF cycles, along the length of the entire cross-section (about $25 \mathrm{~mm}$ ). The crack lengths were then fitted using a Weibull distribution and the material constants were obtained for this TBC system using a modified Paris' law. The modified Paris' law equation was then numerically integrated to estimate the normalized damage as function of the TCF cycles and the curve was compared to the curve obtained from the video camera.

The results of this work showed two important things: Applicability of video camera as a quick and reliable means of estimating damage evolution and the suitability of modelling as tool to understand the damage development.

\section{Paper II: Hot Corrosion mechanism in multi-layer suspension plasma sprayed $\mathrm{Gd}_{2} \mathrm{Zr}_{2} \mathrm{O}_{7}$ /YSZ thermal barrier coatings in the presence of $\mathrm{V}_{2} \mathrm{O}_{5}+\mathrm{Na}_{2} \mathrm{SO}_{4}$}

Corrosion is a widely observed phenomenon in thermal barrier coatings. Corrosion induced damage can rapidly degrade the TBCs and understanding the corrosion mechanism therefore becomes critical. The corrosion mechanism in a SPS columnar structured TBCs is the focus of this paper.

Hot corrosion tests on a two-layer $\mathrm{Gd}_{2} \mathrm{Zr}_{2} \mathrm{O}_{7} / \mathrm{YSZ}$, a three-layer dense $\mathrm{Gd}_{2} \mathrm{Zr}_{2} \mathrm{O}_{7} / \mathrm{Gd}_{2} \mathrm{Zr}_{2} \mathrm{O}_{7}$ and a reference single-layer YSZ have been conducted in the presence of $\mathrm{V}_{2} \mathrm{O}_{5}+\mathrm{Na}_{2} \mathrm{SO}_{4}$. The test temperature was $900{ }^{\circ} \mathrm{C}$ and the time was $8 \mathrm{~h}$. The bond coat and the substrate used in the study were Amdry 9951 and Hastelloy X respectively. All the layers of the top coat were deposited using suspension plasma spraying (SPS), resulting in a columnar structure. The dense layer had a compact structure.

Analysis on the as-corroded samples revealed that $\mathrm{YVO}_{4}$ was formed in $\mathrm{YSZ}$ due to the reaction of the salts with yttria, while $\mathrm{GdVO}_{4}$ was formed in gadolinium zirconate from the reaction of the salts with gadolinia. The amount of $\mathrm{GdVO}_{4}$ formed was lower compared to $\mathrm{YVO}_{4}$ suggesting that the corrosive salts were more reactive with yttria in the reference YSZ coating compared to gadolinia in $\mathrm{Gd}_{2} \mathrm{Zr}_{2} \mathrm{O}_{7}$ based coatings.

Investigations on the cross section of the corroded YSZ showed that due to higher reactivity of the corrosive salts with yttria, the molten salts were immobilized at the upper portion of the coating and the corrosive product, $\mathrm{YVO}_{4}$, was observed inside the pores. For gadolinium zirconate based coatings, due to the lower reactivity of the corrosive salts with yttria, a deeper penetration of the molten salts was observed and the corrosive product was formed between the columns unlike YSZ.

Corrosion induced damage was higher in gadolinium zirconate coatings compared to YSZ, though the former had lower reactivity. The higher damage in gadolinium zirconate coatings was attributed to the combination of material and the microstructure. A low reactive material allowed for a deeper infiltration of the molten salts and the vertical gaps between columns in a columnar microstructure in SPS coatings provided the effective path ways for the molten salts. As the corrosive product was formed between the columnar gaps, thereby sealing them, the 
advantage of the columnar structure in terms of strain tolerance was reduced. This resulted in higher stress build-up in the coating. In addition, a lower fracture toughness of gadolinium zirconate compared to YSZ allowed for extensive cracking within the coating. The dense layer in the three-layer coating, expected to retard the molten salt infiltration, did not show any improvement compared to the two-layer coating. This was due to the fact that the vertical cracks in the third layer could not be avoided as the thickness of the third layer was much smaller (30 $\mu \mathrm{m})$ compared to the combined thickness of the other two layers $(290 \mu \mathrm{m})$.

Low corrosion induced damage in YSZ was explained due to the immobilization of the corrosive salts within the upper part of the coating, formation of the corrosive product within the pores and retention of the columnar structure. In addition, superior fracture toughness of the YSZ helped in reducing the extent of cracking in the coating.

The results of this study revealed the importance of a suitable combination of material and microstructure for having good resistance against corrosive salts.

\section{Paper III: Thermal fatigue failure of thermal barrier coatings with a high Cr-MCrAIY bond coat}

Thermal fatigue of thermal barrier coatings is largely dependent on the bond coat oxidation. The ability of the bond coat to form continuous scale of alumina can influence the lifetime of the TBC. Having a high Cr-low Al bond coat may affect the TCF performance of the TBCs and is the focus of this paper.

The thermal cyclic fatigue (TCF) behavior of a YSZ TBC with a high $\mathrm{Cr}$ - low Al MCrAlY bond coat has been studied. The nominal composition of the bond coat was Ni22Co25Cr7A10.5Y. The substrate used was Hastelloy-X. The thermal cycle was between 100 ${ }^{\circ} \mathrm{C}$ and $1100{ }^{\circ} \mathrm{C}$ with a dwell time of $1 \mathrm{~h}$ at $1100{ }^{\circ} \mathrm{C}$. The samples exhibited a lifetime of about $600-650$ cycles with the failure criterion being $20 \%$ spallation on the top surface.

Cross section analysis on the interrupted test samples revealed the presence of a "sandwich" type of oxide formation with a top layer of chromia and spinels, middle-layer of MCrAlY and a bottom layer of alumina. This type of microstructure was observed during the early stages of the sample's life. With increased exposure, the thickness of the outer-oxide layer was almost the same while the thickness of alumina increased. During this period, the cracks also grew and their coalescence resulted in the final failure. A diffusion model in DICTRA coupled with MATLAB was used for predicting the elemental diffusion.

The results of the above study indicated that coatings with relatively high chromium and low aluminum, which are more preferred for corrosion resistance, may also offer good oxidation resistance during thermal cycling. The coatings' lifetime was similar in comparison to the other conventional bond coats, with low $\mathrm{Cr}$ and high $\mathrm{Al}$ (comparison not presented in the paper). However, the oxidation life of such a coating may be difficult to improve due to the low $\mathrm{Al}$ content in the coating. 


\section{Paper IV: Modelling the diffusion of minor elements in different MCrAIY - Superalloy coating/substrates at high temperature}

Diffusion of elements between the substrate and the bond coat can deteriorate the performance of thermal barrier coating system by changing the properties of both the substrate and the bond coat. Knowledge on the diffusion behavior of elements at high temperature can provide information to understand the microstructure development in a TBC system and is the focus of this paper.

Inter-diffusion of minor elements in different MCrAlY - Superalloy coating/substrates at 1100 ${ }^{\circ} \mathrm{C}$ was studied using the commercial software DICTRA. As oxidation is significant at this temperature in real applications, simultaneous oxidation was also considered by coupling MATLAB with DICTRA. For this study, three commercial substrates, Hastelloy X, Inconel 738 and Waspaloy was used. For coatings, 5 hypothetical compositions were used. The selection of the substrates and the coatings was done with consideration to cover a good composition range.

Simulated profiles show that the diffusion of minor elements in the coating exhibited two stages: a $\beta$-phase (NiAl) depleting stage and a $\beta$-depleted stage. Depletion of the $\beta$-phase occurred due to the difference in Al activity in the substrates and the coating. During the $\beta$ phase depleting stage the coatings exhibited $\gamma+\beta$ microstructure and the diffusion of minor elements in the coatings was observed to be related to the rate of $\beta$-phase depletion. This was due to the dissolution preference of the minor elements in the $\beta$-phase. After the complete depletion of the $\beta$-phase, diffusion of the minor elements was found to have no clear dependence on the coatings composition and it was mainly determined by the substrate composition. This was contributed to the dilution effect of the elements from the substrate.

The results of this study can be used for understanding the diffusion behavior and microstructure evolution at high temperatures in different MCrAlY-substrate systems. 


\section{Conclusions}

From the results of this work, the following are the main conclusions

a. High-purity nano YSZ TBC during thermal cycling showed a mixed-type failure. The cracks initially grew slowly in the top coat and propagated towards the TGO/TC interface where the crack growth had accelerated. With this type of crack growth path, the majority of the damage came towards the end of the coating life.

b. SPS sprayed multi-layer gadolinium zirconate/YSZ coatings showed higher corrosion induced damage compared to a single layer reference YSZ coating. Due to lower reactivity of gadolinium zirconate coatings, the molten salts filled the columnar gaps and reduced the strain tolerance of the coating. This together with the low fracture toughness of gadolinium zirconate resulted in higher coating damage.

c. A high-Cr low-Al MCrAlY bond coat exhibited a good TCF life and was similar to the other conventional bond coat TBCs. Cross sectional investigation revealed the formation of a "sandwich" type oxide structure with chromium rich oxide and alumina as the top and the bottom layers.

d. Diffusion of minor elements between superalloy substrates and MCrAlY coatings seem to be dependent on the rate of $\beta$-phase depletion in the beginning and after the depletion of the $\beta$-phase no clear dependence on the coating composition was observed. 



\section{8}

\section{Future work}

Further research to increase understanding of those issues related to the research questions and their outcomes will be continued. The following are some of the possibilities.

Development of the TBC life model based on the current understanding of the failure controlling mechanisms is a main focus of the future research. The different crack growth paths during thermal cycling are to be incorporated in the life model. Validation of the model is to be done by TCF tests at different temperatures and hold times.

Studying the performance of coatings during corrosion is also one of the focuses. One of the main goals will be to understand the influence of the coating composition on the failure mechanism(s) of TBCs and overlay coated samples when exposed to a sulphur rich environment, or different salt mixtures of sodium sulfate $\left(\mathrm{Na}_{2} \mathrm{SO}_{4}\right)+$ potassium sulfate $\left(\mathrm{K}_{2} \mathrm{SO}_{4}\right)$ or vanadium pentoxide $\left(\mathrm{V}_{2} \mathrm{O}_{5}\right)$ and sodium sulfate $\left(\mathrm{Na}_{2} \mathrm{SO}_{4}\right)$.

In spite of the expected better resistance against sintering for the nano-structured YSZ, our experiments showed that its TCF life was lower than a conventional YSZ coating used as reference (the result was not presented in this thesis). The reason(s) for this could be related to factors such as fracture toughness, elastic modulus, and porosity, which are going to be investigated. Further research work will be carried with the focus to improve the TCF lifetime of high purity nano YSZ coatings by optimizing the deposition process. 



\section{Bibliography}

[1] M.P. Boyce, Gas Turbine Engineering Handbook. Butterworth-Heinemann, Elsevier, 2011.

[2] R.C. Reed, The Superalloys: Fundamentals and Applications. Cambridge University Press, Cambridge, 2006.

[3] M. Segersäll, Nickel-Based Single-Crystal Superalloys - the crystal orientation influence on high temperature properties, Licentiate Thesis, Linköpings Universitet, 2013.

[4] N.P. Padture, M. Gell, and E.H. Jordan, Thermal barrier coatings for gas-turbine engine applications, Science., vol. 296, pp.280-284, 2002.

[5] S. Bose, High Temperature Coatings. Butterworth-Heinemann, Elsevier, 2007.

[6] M. Belmonte, Advanced Ceramic Materials for High Temperature Applications, Adv. Eng. Mater., vol. 8, pp. 693-703, 2008 .

[7] X.Q. Cao, R. Vaßen and D. Stöver, Ceramic materials for thermal barrier coatings, J. Eur. Ceram. Soc., vol. 24, pp. 1-10, 2004.

[8] S. Stecura, Optimization of the Ni-Cr-Al-Y/ $/ \mathrm{ZrO}_{2}-\mathrm{Y}_{2} \mathrm{O}_{3}$ thermal barrier system, Adv. Cer. Mat., vol. 1, pp. 68-76, 1986.

[9] H.G. Scott, Phase relationships in the zirconia-yttria system, J. Mater. Sci., vol. 10, pp. 1527-1535, 1975.

[10] X. Zhao and P. Xiao, Thermal Barrier Coatings on Nickel Superalloy Substrates, Mater. Sci. Forum., vol. 606, pp. 1-26, 2009.

[11] G. Dwivedi, V. Viswanathan, S. Sampath, A. Shyam and E. Lara-Curzio, Fracture Toughness of Plasma-Sprayed Thermal Barrier Ceramics: Influence of Processing, Microstructure, and Thermal Aging, J. Am. Ceram. Soc., vol. 97, pp. 2736-2744, 2014.

[12] X. Zhong, H. Zhao, X. Zhou, C. Liu, L. Wang, F. Shao, K. Yang, S. Tao and C. Ding, Thermal shock behavior of toughened gadolinium zirconate/YSZ double-ceramic-layered thermal barrier coating, J. Alloys Compd., vol. 593, pp. 50-55, 2014.

[13] D.R. Clarke and S.R. Phillpot, Thermal barrier coating materials, Mater. Today., vol. 8, pp. 22-29, 2005. 
[14] R.S. Lima and B.R. Marple, Nanostructured YSZ thermal barrier coatings engineered to counteract sintering effects, Mater. Sci. Eng. A., vol. 485, pp. 182-193, 2008.

[15] C.B. LIU, Z-M. ZHANG, X-L. JIANG, M. LIU and Z.H. ZHU, Comparison of thermal shock behaviors between plasma-sprayed nanostructured and conventional zirconia thermal barrier coatings, Trans. Nonferrous Met. Soc. China, vol. 19, pp. 99-107, 2009.

[16] C. Zhou, N. Wang and $\mathrm{H}$. Xu, Comparison of thermal cycling behavior of plasmasprayed nanostructured and traditional thermal barrier coatings, Mater. Sci. Eng. A., vol. 452453, pp. 569-574, 2007.

[17] H. Jamali, R. Mozafarinia, R.S. Razavi and R. Ahmadi-Pidani, Comparison of thermal shock resistances of plasma-sprayed nano structured and conventional yttria stabilized zirconia thermal barrier coatings, Ceram. Int., vol. 38, pp. 6705-6712, 2012.

[18] J. Wu, H. Guo, L. Zhou, L. Wang and S. Gong, Microstructure and Thermal Properties of Plasma Sprayed Thermal Barrier Coatings from Nanostructured YSZ, J. Therm. Spray Technol., vol. 19, pp. 1186-1194, 2010.

[19] H. Jamali, R. Mozafarinia, R.S. Razavi and R. Ahmadi-Pidani, Comparison of hot corrosion behaviors of plasma-sprayed nanostructured and conventional YSZ thermal barrier coatings exposure to molten vanadium pentoxide and sodium sulfate, J. Eur. Ceram. Soc., vol. 34, pp. 485-492, 2014.

[20] R. Vaßen, M.O. Jarligo, T. Steinke, D.E. Mack and D. Stöver, Overview on advanced thermal barrier coatings, Surf. Coat. Technol., vol. 205, pp. 938-942, 2010.

[21] R. Vaßen, X. Cao, F. Tietz, D. Basu and D. Stöver, Zirconates as New Materials for Thermal Barrier Coatings, J. Am. Ceram. Soc., vol. 83, pp. 2023-2028, 2000.

[22] G. Moskal, L. Swadźba, M. Hetmańczyk, B. Witala, B. Mendala, J. Mendala and P. Sosnowy, Characterization of microstructure and thermal properties of $\mathrm{Gd}_{2} \mathrm{Zr}_{2} \mathrm{O}_{7}$-type thermal barrier coating, J. Eur. Ceram. Soc., vol. 32, pp. 2025-2034, 2012.

[23] J. Wu, X. Wei, N.P. Padture, P.G. Klemens, M. Gell, E. Garciá, P. Miranzo and M.I. Osendi, Low-Thermal-Conductivity Rare-Earth Zirconates for Potential Thermal-Barrier Coating Applications, J. Am. Ceram. Soc., vol. 85, pp. 3031-3035, 2002.

[24] R.M. Leckie, S. Krämer, M. Rühle and C.G. Levi, Thermochemical compatibility between alumina and $\mathrm{ZrO}_{2}-\mathrm{GdO}_{3 / 2}$ thermal barrier coatings, Acta Mater., vol. 53, pp. 32813292, 2005.

[25] R. Vaßen, F. Traeger and D. Stöver, New Thermal Barrier Coatings Based on Pyrochlore/YSZ Double-Layer Systems, Int. J. Appl. Ceram. Technol., vol. 1, pp. 351-361, 2004.

[26] S. Mahade, N. Curry, S. Björklund, N. Markocsan and P. Nylén, Thermal conductivity and thermal cyclic fatigue of multilayered $\mathrm{Gd}_{2} \mathrm{Zr}_{2} \mathrm{O}_{7} / \mathrm{YSZ}$ thermal barrier coatings processed by suspension plasma spray, Surf. Coat. Technol., vol. 283, pp. 329-336, 2015.

[27] W. Brandl, H.J. Grabke, D. Toma and J. Kruger, The oxidation behaviour of sprayed MCrAIY coatings, Surf. Coat. Technol., vol. 87, pp. 41-47, 1996. 
[28] R. Mévrel, State of the art on high-temperature corrosion-resistant coatings, Mater. Sci. Eng. A., vol. 120-121, pp. 13-24, 1989.

[29] R. Eriksson, Thermal Barrier Coatings: Durability Assessment and Life Prediction, Ph.D. dissertation, Linköpings Universitet, 2013.

[30] H. Echsler, D. Renusch and M. Schütze, Bond coat oxidation and its significance for life expectancy of thermal barrier coating systems, Mater. Sci. Technol., vol. 20, pp. 307-318, 2004.

[31] W.R. Chen, X. Wu, B.R. Marple, R.S. Lima and P.C. Patnaik, Pre-oxidation and TGO growth behaviour of an air-plasma-sprayed thermal barrier coating, Surf. Coat. Technol., vol. 202, pp. 3787-3796, 2008.

[32] M.S. Ali, S. Shenhua and P. Xiao, Degradation of thermal barrier coatings due to thermal cycling up to $1150^{\circ} \mathrm{C}$, J. Mater. Sci., vol. 37, pp. 2097-2102, 2002.

[33] E.A.G. Shillington and D.R. Clarke, Spalling failure of a thermal barrier coating associated with aluminum depletion in the bond-coat, Acta Mater., vol. 47, pp. 1297-1305, 1999.

[34] K. Vanevery, M.J.M. Krane, R.W. Trice, H. Wang, W. Porter, M. Besser, D. Sordelet, J. Ilavsky and J. Almer, Column formation in suspension plasma-sprayed coatings and resultant thermal properties, J. Therm. Spray Technol., vol. 20, pp. 817-828, 2011.

[35] N. Curry, Design of Thermal Barrier Coating Systems, Ph.D. dissertation, University West, 2014.

[36] S. Mahade, Functional Performance of Gadolinium Zirconate/Yttria Stabilized Zirconia Multi-Layered Thermal Barrier Coatings, Licentiate Thesis, University West, 2016.

[37] M. Ranjbar-Far, J. Absi, S. Shahidi and G. Mariaux, Impact of the non-homogenous temperature distribution and the coatings process modeling on the thermal barrier coatings system, Mater. Des., vol. 32, pp. 728-735, 2011.

[38] R. Eriksson, H. Brodin, S. Johansson, L. Östergren and X-H. Li, Thermal Cycling Fatigue of Thermal Barrier Coatings - Rig and Experiment Design, Adv. Mater. Res., vol. 891892, pp. 641-646, 2014.

[39] H. Brodin, Failure of thermal barrier coatings under thermal and mechanical fatigue loading : microstructural observations and modelling aspects, Ph.D. dissertation, Linköpings Universitet, 2004.

[40] R. Eriksson, S. Johansson, H. Brodin, E. Broitman, L. Östergren and X-H. Li, Influence of substrate material on the life of atmospheric plasma sprayed thermal barrier coatings, Surf. Coat. Technol., vol. 232, pp. 795-803, 2013.

[41] H. Peng, H. Guo, R. Yao, J. He and S. Gong, Improved oxidation resistance and diffusion barrier behaviors of gradient oxide dispersed NiCoCrAlY coatings on superalloy, Vacuum., vol. 85, pp. 627-633, 2010.

[42] R. Vaßen, F. Cernuschi, G. Rizzi, A. Scrivani, N. Markocsan, L. Östergren, A. Kloosterman, R. Mevrel, J. Feist and J. Nicholls, Recent activities in the field of thermal barrier 
coatings including burner rig testing in the European Union., Adv. Eng. Mater., vol. 10, pp. 907-921, 2008.

[43] S. Ahmaniemi, P. Vuoristo, T. Mäntylä, C. Gualco, A. Bonadei and R. Di Maggio, Thermal cycling resistance of modified thick thermal barrier coatings, Surf. Coat. Technol., vol. 190, pp. 378-387, 2005.

[44] W. Ma, D.E. Mack, R. Vaßen and D. Stöver, Perovskite-Type Strontium Zirconate as a New Material for Thermal Barrier Coatings, J. Am. Ceram. Soc., vol. 91, pp. 2630-2635, 2008.

[45] N. Eliaz, G. Shemesh and R.M. Latanision, Hot corrosion in gas turbine components, Eng. Fail. Anal., vol. 9, pp. 31-43, 2002.

[46] P. Mohan, B. Yuan, T. Patterson, V.H. Desai and Y.H. Sohn, Degradation of YttriaStabilized Zirconia Thermal Barrier Coatings by Vanadium Pentoxide, Phosphorous Pentoxide, and Sodium Sulfate, J. Am. Ceram. Soc., vol. 90, pp. 3601-3607, 2007.

[47] A. Afrasiabi, M. Saremi and A. Kobayashi, A comparative study on hot corrosion resistance of three types of thermal barrier coatings: $\mathrm{YSZ}, \mathrm{YSZ}+\mathrm{Al}_{2} \mathrm{O}_{3}$ and $\mathrm{YSZ} / \mathrm{Al}_{2} \mathrm{O}_{3}$, Mater. Sci. Eng. A., vol. 478, pp. 264-269, 2008.

[48] K.P. Jonnalagadda, S. Mahade, N. Curry, X-H. Li, N. Markocsan, P. Nylén, S. Björklund and R.L. Peng, Hot Corrosion Mechanism in Multi-Layer Suspension Plasma Sprayed $\mathrm{Gd}_{2} \mathrm{Zr}_{2} \mathrm{O}_{7} / \mathrm{YSZ}$ Thermal Barrier Coatings in the Presence of $\mathrm{V}_{2} \mathrm{O}_{5}+\mathrm{Na}_{2} \mathrm{SO}_{4}, \mathrm{~J}$. Therm. Spray Technol., vol. 26, pp. 140-149, 2017.

[49] M.H. Habibi, L. Wang and S.M. Guo, Evolution of hot corrosion resistance of YSZ, $\mathrm{Gd}_{2} \mathrm{Zr}_{2} \mathrm{O}_{7}$, and $\mathrm{Gd}_{2} \mathrm{Zr}_{2} \mathrm{O}_{7}+\mathrm{YSZ}$ composite thermal barrier coatings in $\mathrm{Na}_{2} \mathrm{SO}_{4}+\mathrm{V}_{2} \mathrm{O}_{5}$ at 1050 ${ }^{\circ} \mathrm{C}$, J. Eur. Ceram. Soc., vol. 32, pp. 1635-1642, 2012.

[50] K.P. Jonnalagadda, R. Eriksson, R.L. Peng, X-H. Li and S. Johansson, Factors Affecting the Performance of Thermal Barrier Coatings in the Presence of $\mathrm{V}_{2} \mathrm{O}_{5}$ and $\mathrm{Na}_{2} \mathrm{SO}_{4}, \mathrm{~J}$. Ceram. Sci. Technol., vol. 7, pp. 409-416, 2016.

[51] Z. Chen, S. Speakman, J. Howe, H. Wang, W. Porter and R. Trice, Investigation of reactions between vanadium oxide and plasma-sprayed yttria-stabilized zirconia coatings, J. Eur. Ceram. Soc., vol. 29, pp. 1403-1411, 2009.

[52] R. Ahmadi Pidani, R. S. Razavi, R. Mozafarinia and H. Jamali, Comparison of Hot Corrosion Resistance of YSZ and CYSZ Thermal Barrier Coatings in Presence of SulfateVanadate Molten Salts, Adv. Mater. Res., vol. 472-475, pp. 141-144, 2012.

[53] Z. Chen, J. Mabon, J-G. Wen and R. Trice, Degradation of plasma-sprayed yttriastabilized zirconia coatings via ingress of vanadium oxide, J. Eur. Ceram. Soc., vol. 29, pp. 1647-1656, 2009.

[54] A. Keyvani, M. Saremi and M. Heydarzadeh Sohi, Microstructural stability of zirconiaalumina composite coatings during hot corrosion test at $1050^{\circ} \mathrm{C}$, J. Alloys Compd., vol. 506, pp. 103-108, 2010.

[55] Z-G. Liu, J-H. Ouyang, Y. Zhou and S. Li, High-temperature hot corrosion behavior of gadolinium zirconate by vanadium pentoxide and sodium sulfate in air, J. Eur. Ceram. Soc., vol. 30, pp. 2707-2713, 2010. 
[56] S.Y. Park, J.H. Kim, M.C. Kim, H.S. Song and C.G. Park, Microscopic observation of degradation behavior in yttria and ceria stabilized zirconia thermal barrier coatings under hot corrosion, Surf. Coat. Technol., vol. 190, pp. 357-365, 2005.

[57] R. Ahmadi-Pidani, R. Shoja-Razavi, R. Mozafarinia and H. Jamali, Evaluation of hot corrosion behavior of plasma sprayed ceria and yttria stabilized zirconia thermal barrier coatings in the presence of $\mathrm{Na}_{2} \mathrm{SO}_{4}+\mathrm{V}_{2} \mathrm{O}_{5}$ molten salt, Ceram. Int., vol. 38, pp. 6613-6620, 2012.

[58] M.H. Habibi and S.M. Guo, The hot corrosion behavior of plasma sprayed zirconia coatings stabilized with yttria, ceria, and titania in sodium sulfate and vanadium oxide, Mater. Corros., vol. 66, pp. 270-277, 2015.

[59] M.R. Loghman-Estarki, M. Nejati, H. Edris, R.S. Razavi, H. Jamali and A.H. Pakseresht, Evaluation of hot corrosion behavior of plasma sprayed scandia and yttria costabilized nanostructured thermal barrier coatings in the presence of molten sulfate and vanadate salt, J. Eur. Ceram. Soc., vol. 35, pp. 693-702, 2015.

[60] C. Liu, H. Huang, L. Ni and C. Zhou, Evaluation of Thermal Barrier Coatings Exposed to Hot Corrosion Environment by Impedance Spectroscopy, Chinese J. Aeronaut., vol. 24. pp. 514-519, 2011.

[61] S. Pahlavanyali, A. Sabour and M. Hirbod, The hot corrosion behaviour of HVOF sprayed MCrAlX coatings under $\mathrm{Na}_{2} \mathrm{SO}_{4}(+\mathrm{NaCl})$ salt films, Mater. Corros., vol. 54, pp. 687693, 2003.

[62] G. Sreedhar and V.S. Raja, Hot corrosion of $\mathrm{YSZ} / \mathrm{Al}_{2} \mathrm{O}_{3}$ dispersed NiCrAlY plasmasprayed coatings in $\mathrm{Na}_{2} \mathrm{SO}_{4}-10$ wt.\% NaCl melt, Corros. Sci., vol. 52, pp. 2592-2602, 2010.

[63] R. Mobarra, A.H. Jafari and M. Karaminezhaad, Hot corrosion behavior of MCrAlY coatings on IN738LC, Surf. Coat. Technol., vol. 201, pp. 2202-2207, 2006.

[64] K. Yuan, R.L. Peng, X-H. Li, A. Talus, S. Johansson and Y-D. Wang, Hot corrosion of MCrAlY coatings in sulphate and $\mathrm{SO}_{2}$ environment at $900{ }^{\circ} \mathrm{C}$ : Is $\mathrm{SO}_{2}$ necessarily bad?, Surf. Coat. Technol., vol. 261, pp. 41-53, 2015.

[65] Y. Song, C. Zhou and H. Xu, Corrosion behavior of thermal barrier coatings exposed to $\mathrm{NaCl}$ plus water vapor at $1050{ }^{\circ} \mathrm{C}$, Thin Solid Films., vol. 516, pp. 5686-5689, 2008.

[66] T. Liu, S-W. Yao, L-S. Wang, G-J. Yang, C-X. Li and C-J. Li, Plasma-Sprayed Thermal Barrier Coatings with Enhanced Splat Bonding for CMAS and Corrosion Protection, J. Therm. Spray Technol., vol. 25, pp. 213-221, 2016.

[67] P. Mohan, V. Desai, Y. Sohn, and T. Patterson, Degradation of Thermal Barrier Coatings by Molten CMAS (CaO-MgO- $\left.\mathrm{Al}_{2} \mathrm{O}_{3}-\mathrm{SiO}_{2}\right)$ Deposits, 47th AIAA Aerospace Sciences Meeting including The New Horizons Forum and Aerospace Exposition, 5-8 January, Orlando, Florida, 2009.

[68] B.S. Senturk, H.F. Garces, A.L. Ortiz, G. Dwivedi, S. Sampath and N.P. Padture, CMAS-Resistant Plasma Sprayed Thermal Barrier Coatings Based on $\mathrm{Y}_{2} \mathrm{O}_{3}-$ Stabilized $\mathrm{ZrO}_{2}$ with $\mathrm{Al}^{3+}$ and $\mathrm{Ti}^{4+}$ Solute Additions, J. Therm. Spray Technol., vol. 23, pp. 708-715, 2014. 
[69] S. Krämer, J. Yang, C.G. Levi and C.A. Johnson, Thermochemical Interaction of Thermal Barrier Coatings with Molten CaO-MgO- $\mathrm{Al}_{2} \mathrm{O}_{3}-\mathrm{SiO}_{2}$ (CMAS) Deposits, J. Am. Ceram. Soc., vol. 89, pp. 3167-3175, 2006.

[70] C. Mercer, S. Faulhaber, A.G. Evans and R. Darolia, A delamination mechanism for thermal barrier coatings subject to calcium-magnesium-alumino-silicate (CMAS) infiltration, Acta Mater., vol. 53, pp. 1029-1039, 2005.

[71] A. Borgenstam, A. Engström, L. Höglund and J. Ågren, DICTRA, a Tool for Simulation of Diffusional Transformations in Alloys, J. Phase Equilibria., vol. 21, pp. 269-280, 2000.

[72] H. Chen, K. Zhou, Z. Jin and C. Liu, Diffusion and Phase Transformation on Interface Between Substrate and NiCrAlY in Y-PSZ Thermal Barrier Coatings, J. Therm. Spray Technol., vol. 13, pp. 515-520, 2004.

[73] K.V. Dahl, J. Hald and A. Horsewell, Interdiffusion between Ni-based superalloy and MCrAlY coating, Defect Diffus. Forum., vol. 258-260, pp. 73-78, 2006.

[74] A. Jung and A. Schnell, Crack growth in a coated gas turbine superalloy under thermomechanical fatigue, Int. J. Fatigue., vol. 30, pp. 286-291, 2008.

[75] K. Yuan, R. Eriksson, R.L. Peng, X-H. Li, S. Johansson and Y-D. Wang, MCrAlY coating design based on oxidation-diffusion modelling. Part I: Microstructural evolution, Surf. Coat. Technol., vol. 254, pp. 79-96, 2014.

[76] K. Yuan, R. Eriksson, R.L. Peng, X-H. Li, S. Johansson and Y-D. Wang, Modeling of microstructural evolution and lifetime prediction of MCrAlY coatings on nickel based superalloys during high temperature oxidation, Surf. Coat. Technol., vol. 232, pp. 204-215, 2013.

[77] A. Rabiei and A.G. Evans, Failure Mechanisms Associated with the Thermally Grown Oxide in Plasma Sprayed Thermal Barrier Coatings, Acta Mater., vol. 48, pp. 3963-3976, 2000.

[78] J. DeMasi, K. Sheffler and M. Ortiz, Thermal Barrier Coating Life Prediction Model Development Phase I -Final Report, NASA, NASA Lewis Research Center 210000 Brookpark Road Cleveland, Ohio 44135, Tech. Rep. Nasa-CR-182230, 1989.

[79] M. Jinnestrand, Delamination in APS applied thermal barrier coatings : life modelling, Ph.D. dissertation, Linköpings Universitet, 2004.

[80] S. Sjöström, H. Brodin and M. Jinnestrand, Proceedings of 13th International Conference on Fracture, 16-21 June, Beijing, China, 2013.

[81] R. Eriksson and K.P. Jonnalagadda, A Study on Crack Configurations in Thermal Barrier Coatings, Submitted to ASME Turbo Expo, 26-30 June, North Carolina, USA, 2017.

[82] A. Kulkarni, A. Vaidya, A. Goland, S. Sampath and H. Herman, Processing effects on porosity-property correlations in plasma sprayed yttria-stabilized zirconia coatings, Mater. Sci. Eng. A., vol. 359, pp. 100-111, 2003.

[83] Z. Wang, A. Kulkarni, S. Deshpande, T. Nakamura and H. Herman, Effects of pores and interfaces on effective properties of plasma sprayed zirconia coatings, Acta Mater., vol. 51, pp. 5319-5334, 2003. 
[84] C.A. Schneider, W.S. Rasband and K.W. Eliceiri, NIH Image to ImageJ: 25 years of image analysis, Nat. Methods., vol. 9, pp. 671-675, 2012.

[85] W.J. Brindley and T.A. Leonhardt, Metallographic techniques for evaluation of thermal barrier coatings, Mater. Charact., vol. 24, pp. 93-101, 1990.

[86] A. Ganvir, Microstructure and Thermal Conductivity of Liquid Feedstock Plasma Sprayed Thermal Barrier Coatings, Licentiate Thesis, University West, 2016.

[87] ASTM Standard E562 (2002), "Standard Test Method for Determining Volume Fraction by Systematic Manual Point Count”, ASTM International, 2002.

[88] J. Goldstein, D. Newbury, D. Joy, C. Lyman, P. Echlin, E. Lifshin, L. Sawyer and J. Michael, Scanning Electron Microscopy and X-Ray Microanalysis. Springer, 2003. 


\section{Papers}

The articles associated with this thesis have been removed for copyright reasons. For more details about these see:

http://urn.kb.se/resolve? urn:nbn:se:liu:diva-134379 